\title{
The Path of Petrila Mining Area towards Future Industrial Heritage Tourism Seen through the Lenses of Past and Present
}

\author{
Andreea Ionica ${ }^{1}\left(\mathbb{D}\right.$, Ionela Samuil ${ }^{2}$, Monica Leba ${ }^{3, *(1)}$ and Mihaela Toderas ${ }^{4}$ \\ 1 Management and Industrial Engineering Department, University of Petrosani, 332006 Petrosani, Romania; \\ andreeaionica@upet.ro \\ 2 Management and Engineering Doctoral Field, University of Petrosani, 332006 Petrosani, Romania; \\ ionelasamuil@gmail.com \\ 3 Computer and System Control Department, University of Petrosani, 332006 Petrosani, Romania \\ 4 Mining Engineering Department, University of Petrosani, 332006 Petrosani, Romania; \\ mihaelatoderas@upet.ro \\ * Correspondence: monicaleba@upet.ro; Tel.: +40-736-980865
}

Received: 24 October 2020; Accepted: 23 November 2020; Published: 27 November 2020

\begin{abstract}
The paper explores the industrial tourism development potential of a former mining area in Petrila, Jiu Valley, Romania, drastically affected by deindustrialization, in order to build a theme park in the old mine site. The research context is determined by the current economic and social state of the area, and also by the potential of the identified industrial heritage elements. For this reason, there was developed an optimal selection algorithm, based on multi-criteria analysis and Greedy approach. This optimal selection algorithm blends the objectivity of the technical-economic studies and the subjectivity of the residents' perceptions of community satisfaction. After carrying out the Petrila case study, the results of the proposed algorithm application concerning the destination, from the point of view of their use, of each existing building in the Petrila site was determined. Compared with other studies, ours considers different criteria and can always be reapplied to validate or refine the selection based on new emerging inputs.
\end{abstract}

Keywords: creative industrial tourism; post-mining; residents; community; theme park; greedy; multi-criteria

\section{Introduction}

The paper explores the industrial heritage tourism (IHT) development potential of a former mining area in the Jiu Valley, Romania, drastically affected socially and economically by deindustrialization, in order to build a theme park in the old mine site. This park gives the opportunity to maintain and generate new creative events, adding to the already existing ones.

The research context is determined by the current economic and social state regarding the above-mentioned area, and also by the potential of the identified industrial heritage elements included in the Heritage List, completed by the initiation of several projects for social, cultural and educational events in the context of IHT.

The research perspective is to valorize the industrial heritage through tourism. Previous studies covered different areas and topics, including mines. Former mining enclosures that include underground and/or surface sites give tourists genuine and novel experiences. In addition, by highlighting the value of the local industrial past, it may also enhance residents' identity self-awareness and encourage integration in an increasingly globalized world [1]. 
For the studied area (Jiu Valley), generally, tourism is considered in the analysis of an alternative scenario of economic development due to the potential multiplied impact in its own sector and for the rest of the activity sectors in the region, but specifically, the potential of IHT development is not taken into consideration yet. In 2007, Jiu Valley was included in a Platform for Coal Regions in Transition and studies were developed to replace the current mono-industrial profile based on coal and energy, following the principles imposed by the concept of "fair transition" that will benefit the whole community by involving all stakeholders. Unfortunately, all remained as studies which were never implemented.

Previous studies [2] show that community-based tourism (CBT) plays an important role in poverty eradication by revitalization of areas affected by mono-industrial exploitation. For this, the positive and negative effects must be evaluated. Positive or negative perception of the locals is essential in CBT, as they can support or obstruct the development of tourism [3]. The evolution of the perception of the locals has been studied at different levels [4-6]. CBT was chosen to be explored as a possible solution in the future, due to the potential contribution of the community related traditions, through traditional handmade products, former employees used for storytelling, traditional culinary recipes, traditional cultural events, traditional products workshops.

The present research is in the pre-development phase of CBT, in which the residents are considered key stakeholders. In fact, we are talking about the pre-development phase of CBT based on industrial heritage.

Ref. [7] says that the success of industrial tourism development depends on the consideration of the resources like buildings, landscapes and people and in [1] it is said that each IHT project has complex attributes (social, economic, environmental, historical, religious, emotional). There is a need to find a way to make the most of the industrial heritage, taking into account the perceptions of the locals. The materialization will be the design of the structural elements of the theme park (buildings) with the most suitable optimal destinations according to predefined criteria. For this we propose an optimal algorithm for selection of destinations in the context of industrial heritage for tourism development.

The algorithm for obtaining the optimal solution blends objectivity with subjectivity-the objectivity of the technical-economic studies and the subjectivity given by the residents' perceptions of community satisfaction. Following the study of the specialized literature on the key attributes of the IHT and the results of the preliminary studies, the input elements (resulting from the technical, economic and social study) of the algorithm were identified.

We carry out a case study in Petrila, Jiu Valley (Romania) to assess the results of the proposed algorithm application. In further research, proposals to design a theme park based on the best suited destinations generated by the algorithm for each building will be made.

The rest of the paper is organized as follows: Section 2 presents a literature review, Section 3 the materials and methods used, including a study area map, a process diagram and the proposed optimal algorithm; Section 4 describes, in a case study, the results of applying the algorithm for valorization of the Petrila's industrial heritage. The results of two preliminary studies, one concerning the technical solutions needed for rehabilitation of the buildings and the other concerning the residents' attitude towards tourism development will be presented also. Section 5 provides the main results, Section 6 discussions and Section 7 conclusions, limitations and further enhancements.

\section{Literature Review}

The previous approaches to industrial tourism and interpretations of the type "industry as a tourist attraction" confirm that industrial tourism is proving to be an appealing constantly evolving topic ready to be further explored and enriched.

While some approaches use the term of "tourism as an industry", others use terms that are more or less equal to industrial tourism, as follows: "factory tourism" [8], "agricultural tourism" [9], "farm stays" [10], "work displays" [11], "workplaces" [12], "factory tourism" [13], "wine tourism" [14] or "sideline tourism" [15]. While in [16] the concept of industrial tourism is defined as the process 
of presenting "contemporary manufacturing processes", in [17] industrial tourism is described as representing "visits by consumers to the site of a production facility and can include educational tours of the facility and tasting of the product that is produced". Contrary to [16], in [18] industrial tourism is defined as "tourist visits to operational sites where the core activity is not tourism oriented" and states that industrial tourism covers all firms opening their gates for industrial tourists. According to the point of view of [19], industrial tourism represents "visits to sites that allow visitors to learn about the economic activities of the past, present and future", offering a broader definition of the concept.

As a summary, we can say that industrial tourism represents the visit of sites that allow visitors to learn about past activities, to observe the present and to project the future so that tourists who choose to visit a site, operational or post-exploitation, may be interested, not only in the economic activities of the firm's past, but also in other types of activities carried out over time, perhaps wanting to understand its evolution so far, based on these elements trying to make a projection in the future. This way, the tourist is faced with the opportunity to discover its creative potential based on observing and learning the past and present of the industrial site.

Industrial tourism is generally considered a form of cultural heritage tourism, focused on historical sites, being already addressed in previous research [20-23], but IHT constitutes a distinct under-researched subset of it, focused on the development of activities and tourist industries on sites, buildings and landscapes created by man in the industrial processes of previous periods. The word "inheritance" has been used to denote a large number of phenomena of different types, such as cultural, artistic, archaeological, historical, religious, military, natural and picturesque [23]. With regard to those mentioned, the interest has always been subjective, favoring and protecting some relics and ignoring others. Castles, churches and cathedrals, museums and other buildings, associated with a historical period, have received attention and recognition, while most other vestiges, generally related to productive activities considered responsible for environmental degradation and landscape damage, have been neglected.

The development of IHT was triggered by the recognition of the technological structures as monuments of the past epoch and by the appreciation of their cultural and artistic value. Increasing the importance of industrial tourism has had a positive impact on regional development and an influence on economic growth mitigating the effects of industrial restructuring on labor markets by creating new positions in the services sector. The use of industrial heritage resources for tourism is advantageous for economic development, both locally and nationally. IHT is often cited as a means by which urban areas can offset the effects of economic restructuring [24,25] and increase the tourism profile of cities and regions [26]. The shift of the industrial landscapes from the production centers to the places of consumption can involve many cultural changes in the local communities that choose the IHT development.

Industrial heritage was defined as "the development of visitor activities and industries on sites built by people, buildings and landscapes that have arisen as a result of industrial processes from previous periods" [27]. Ref. [28] refers to old, abandoned factories and mines using the terms "post-industrial" landscapes. Over time, important industrial relics from the cities that have faced deindustrialization have gradually come to be regarded as sites of industrial heritage and in many countries, they are preserved and transformed into valuable assets for regeneration [29]. So, the industrial heritage becomes increasingly a resource for building new social identities and developing IHT [30].

Abandoned industrial sites are reflections of the economy and society of ancient times, and the landscapes of nostalgia [31], so called because these sites provided jobs for thousands of people and contributed to economic growth in the industrial period [32]. Nowadays, these are sources for the memories of the past, of the industry and community built around factories and mines. Exploring the site can provide an opportunity to find out about the past by preserving the memories, by transforming the abandoned buildings into visitor centers, it can provide jobs, it can help revitalize and develop the community by generating income. By reopening and transforming the sites into tourist objectives, a tourist component can be added to the post-industrial landscape and those who once worked in 
factories or lived in the adjacent communities can become tour guides by actually doing tours of former homes and jobs. However, in many cases, these areas are contested landscapes, where either working and living conditions could have been quite harsh or the factory or mine were responsible for significant environmental damage. If the site is revived as a tourist attraction, the difficulty arises when deciding which buildings to keep, what destination to set for each preserved building and what stories to tell about the past.

Industrial tourism is generally considered to be a form of tourism based on industrial facilities and their associated spaces, comprising not only the vestiges of former companies or the structures of those still operating, but also other elements typical of the industrial era, such as workers' settlements, with specific houses that reflect the lifestyle of the workers and which are now being studied and visited. The idea of visiting active or non-active companies has been around since the 17th century when the British nobility began to travel on the European continent [33], and examples of organized forms of early industrial tourism have been found in the Netherlands since the 19th century (flower markets, cheese factories), France (vineyards, chocolate factories, tobacco factories, stock exchanges), Greece and Malta (lace weavers) [18] as well as in the United States (chocolate factories, distilleries) [11].

Britain was the first country in Europe to face the industrial decline, which resulted in many abandoned factories that were initially visited only by industrial archaeologists, but in the 1980s some regions became aware of their potential industrial heritage [24,34] and there was noticed [35] a true euphoria regarding the industrial heritage with 145 million visitors in 2666 attractions. Since then, other European regions-such as Ruhr area in Germany-have discovered IHT as an interesting element of their economic restructuring policies.

In 1988, the British Tourism Authority initiated the "See industry at work" [35] campaign, which is considered to be one of the first initiatives to promote the visiting of active companies. The campaign inspired other countries, regions and cities to take similar initiatives. In the 1990s, Rotterdam (Netherlands) developed an industrial tourism circuit. In 2000, the York area from Pennsylvania (USA) launched the "Factory Tour Capital of the World" brand. A year later, in 2001, the French region Pays from the Loire Valley established an organization called "Visit our companies" with the aim of improving the industrial tourism offer. In 2005, a center for the promotion of industrial tourism was set up in Shanghai, while the Italian city Turin launched the program "Made in Turin: The Tour of Excellence". In 2006, the city of Anger in the Pays region of the Loire Valley hosted the first conference on the theme of "Company Visit", paying attention to industrial tourism opportunities for companies, regardless of the area in which they were located, both in rural areas and in metropolitan regions. Other examples of regions and cities with industrial tourism programs are: Amsterdam (Netherlands), Nagoya (Japan), the Alps of the Rhone (France) and Western Australia. Two examples are Dabrowa Górnicza in Poland where post-industrial facilities have been transformed into a complex of leisure facilities with lakes, the so-called "Mazurian lakes of Silesia" with underground tracks in the Guido mine in Zabrze or the Historical Silver Mine in Tarnowskie Góry and Sawahlunto in Indonesia where natural beauty, mining heritage sites, museums and architectural features are the most appreciated resources by visitors [36].

Thus, the present research is addressed towards the general context of the increasing interest in IHT [37-40] to which the authors of [41] add landmarks regarding the motivation to experience the past and present periods at a tourist destination [42-44] and aspects regarding the authenticity of tourism destinations in relation to the management of heritage tourism [45-47].

\section{Materials and Methods}

\subsection{Study Area}

Today's society requires the promotion of economic activities to integrate environmental and social concerns, in order to produce genuine and sustainable development over time. Such concepts 
must be at the base of the sustained development of Romania and form the framework of the necessary changes. Romania's mining industry has experienced a serious decline in recent years, going through a major restructuring process. The World Bank has supported the Government of Romania both financially and through technical expertise activities aimed at mine closures, precisely in an attempt to alleviate serious environmental and social problems related to these closures.

The history of the Jiu Valley (Table 1) is certainly linked to the discovery and exploitation of the coal deposits. The extensive industrialization process of the second half of the communist period has led to significant flows of migration to the mining cities of the Jiu Valley, with an obvious impact on the population growth, reaching 167,456 inhabitants in 1992 according to the records of the Hunedoara County Statistics Department. The massive restructuring followed by the mine closure negatively affected both the number of inhabitants and the number of employees in the extractive industry (the number of employees was reduced from 60,679 registered in 1989 to only 3767 in 2017). The city of Petrila, with 24,417 inhabitants, is located in the eastern part of the depression, along the eastern Jiu.

Table 1. Table of history for Jiu Valley extractive industry.

\begin{tabular}{|c|c|c|}
\hline 1855 & The first geological ex & rations in Jiu Valley \\
\hline \multirow[t]{2}{*}{1859} & Petrila is officially the first mining perimeter in $\mathrm{tl}$ & iu Valley and the deepest coal mine in Europe \\
\hline & $\begin{array}{l}\text { The extensive industrialization process of the } \\
\text { significant flows of migration to the mining citie } \\
\text { populatio }\end{array}$ & $\begin{array}{l}\text { ond half of the communist period has led to } \\
\text { f the Jiu Valley, with an obvious impact on the } \\
\text { growth }\end{array}$ \\
\hline \multirow[t]{2}{*}{1989} & 60,679 employees in $t$ & extractive industry \\
\hline & $\begin{array}{l}\text { The massive restructuring followed by the mine } \\
\text { inhabitants and the number of em }\end{array}$ & $\begin{array}{l}\text { osure; negatively affected both the number of } \\
\text { oyees in the extractive industry }\end{array}$ \\
\hline 2017 & 3767 employees in th & xtractive industry \\
\hline \multirow{3}{*}{2030} & Scen & \\
\hline & I. inaction scenario & \multirow{2}{*}{$\begin{array}{l}\text { III. development of the primary, secondary } \\
\text { and tertiary sectors in the period 2020-2030 }\end{array}$} \\
\hline & $\begin{array}{l}\text { II. modernization of one of the mines and the } \\
\text { gradual closure of four others by } 2030\end{array}$ & \\
\hline
\end{tabular}

Currently closed, the Petrila Mining Exploitation has been in operation since 1859, being the oldest mine in the Jiu Valley (about 160 years). As a result of the former coal exploitation, there are tens of hectares deserted or occupied by old buildings, prepared for demolition and disused machinery. According to the authors of [48], the adaptive reuse of industrial buildings is considered an "important recycling tool that is intended to protect and restore important buildings from the point of historical views that have a solid structure".

Like all cities in the Jiu Valley and, in fact, all post-industrial cities, Petrila is looking for a formula for rebirth. A suitable strategy to take into account is the restoration of the industrial heritage from the perimeter of the former Petrila Mining Assembly, the conversion into a touristic objective and its inclusion in a touristic circuit along with other natural and anthropic attractions from the area. Due to the passion and sustained work of the recently established organization Planet Petrila, important perimeter objectives such as: Mechanical Workshops (1879), Compressor building (1879), Thermal power station with chimney (1912), Deak shaft (1868), Shaft with Skip (1987), Shaft Center-Tower and Hall (1938), Old Preparation-with the Coal Laundry (1931), were included in the National Heritage Lists. These perimeter objectives witnessed several creative events, like the "Petrila Planet" movie, Robotics Valley exhibition, underground electronic music concerts and folk concerts. The present research contributes to the premises and the framework for conducting such creative cultural events.

Some possible scenarios of economic development for the Jiu Valley [49] have been presented based on data and estimates of the economic impact, analyzing two scenarios that involve, on the one hand, 
the complete abandonment of the mining operations, and on the other hand, the continuation, on a smaller scale of this activity together with other three alternative scenarios of economic development.

The first is an inaction scenario and assumes that no action is being taken to compensate for job losses, so that the negative economic and social impact is estimated to be close to 1 billion Euro and the loss of 6528 jobs. There is a strong interdependence between the energy sector and other economic sectors, the most affected, as number of jobs lost, being the manufacturing industry (893), the service sector (368), but also the extractive industry (292).

A second scenario involves the modernization of one of the mines and the gradual closure of four others by 2030. In this case the negative economic and social impact is estimated to be of almost 0.5 billion Euro and the loss of 3252 jobs in the total economy, of which the majority are in the manufacturing industry (448), construction (73) and professional and administrative services (204).

The other three scenarios of economic development present alternatives for the development of the primary, secondary and tertiary sectors in the period 2020-2030, on different types of activities that are under-utilized in the Jiu Valley.

Thus, identifying key areas that can be harnessed to increase the involvement of the inhabitants can help a fair post-carbon transition.

It is obvious that the closure of all the mines will generate significant negative economic and social effects. Instead, the alternative activities offer opportunities directly generating over 2500 jobs and support for a diversified economy, not only in terms of different economic branches, but also in terms of created and sustained job types.

Completing the list with IHT, which is not yet exploited in this region, will increase the value of the tertiary sector in this alternative scenario, opening new development opportunities.

In order to actually create an opportunity for social, economic and environmental improvement of Petrila city and not to remain only a wishful project, the following aspects, or even concerns, must be considered: the support from the local government (Hunedoara County Council) for the legal and financial issues of the Petrila mine site; the actual implementation of partnerships between different kinds of stakeholders, especially local business owners and local entrepreneurs, and also a stronger private-public partnership that links the two above mentioned stakeholders. The valorization of IHT in Petrila is carried out on certain evidence and several preliminary studies that lead to solutions, namely Petrila Theme Park, based on a proposed optimal algorithm, as seen in Figure 1.

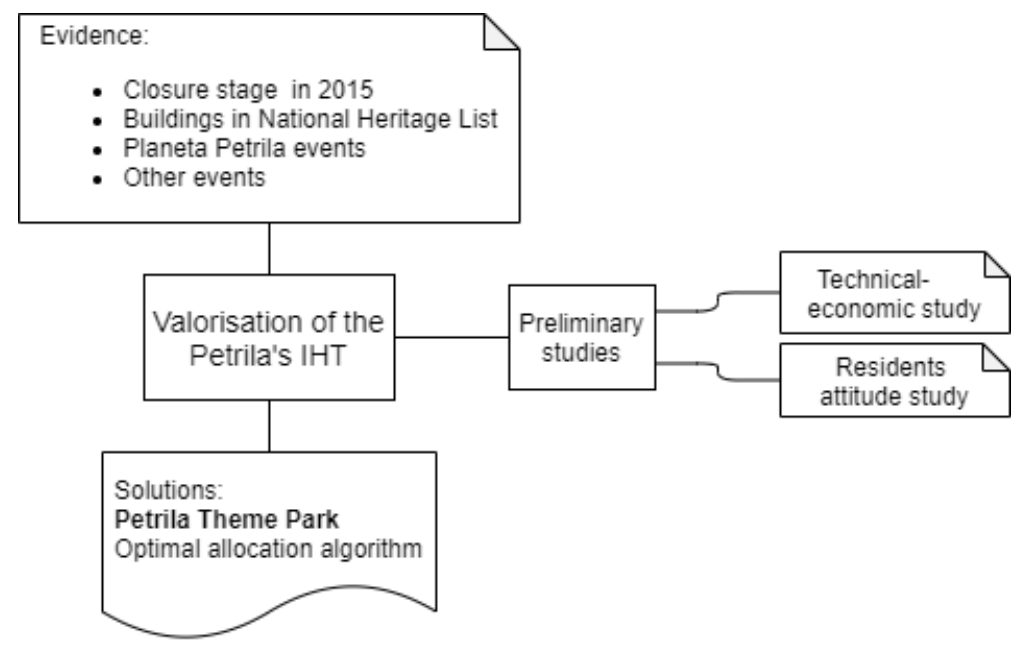

Figure 1. Study area map.

Aspects such as the restoration potential of buildings from the technical point of view, considering also the costs and the duration of the intervention, as well as the perceptions of the locals regarding the development of IHT, will be presented in the following parts being considered as preliminary studies. The results of these preliminary studies were important for outlining the premises for design and 
implementation of an algorithm for optimal selection of the destinations of the buildings. Figure 2 presents a simplified diagram for the involved processes that are further detailed in the paper sections.

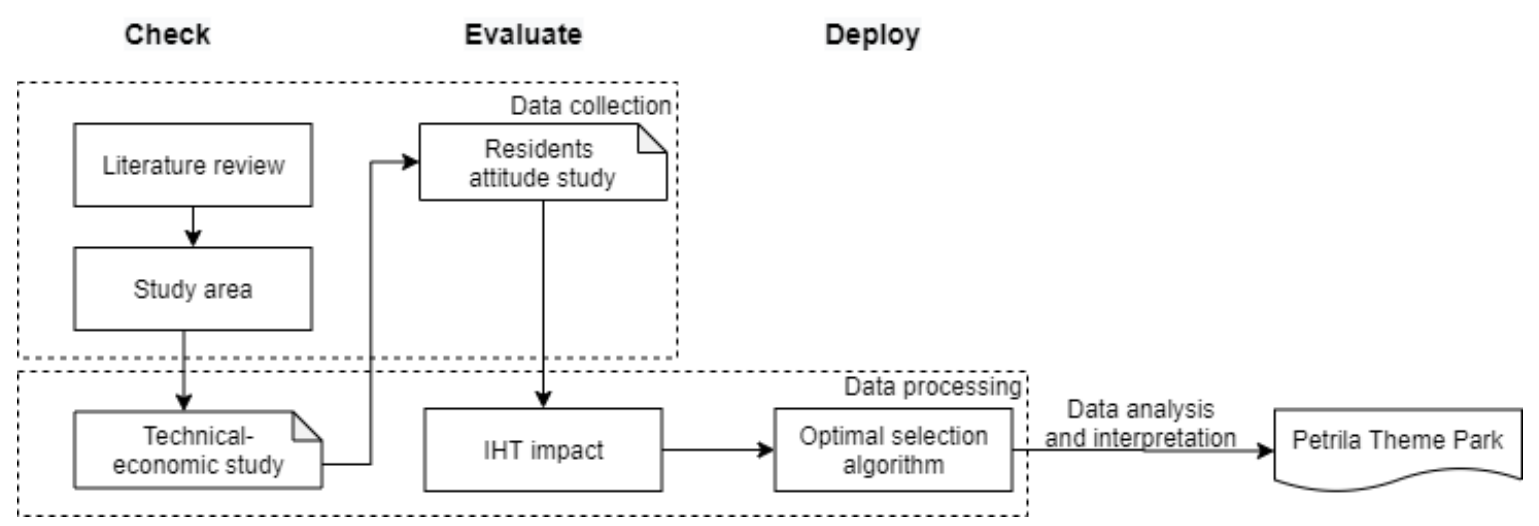

Figure 2. Process diagram.

The process diagram is developed on the three specific stages: Check, Evaluate, Deploy. Thus, in the Check stage, the data collection is made through the study of the scientific literature, the study of the research area and the data processing through the technical-economic study made in the site of the old Petrila mine. In the Evaluate stage, the data collection continues by studying the attitude of the residents from the studied area regarding the development of local tourism and the data processing is completed with the determination of the IHT impact on the community based on the previously collected data. The Deploy stage completes the data processing through the algorithm of optimal selection of tourist destinations for the existing buildings in the Petrila area, which leads to the analysis and interpretation of data for the development of the Petrila Theme Park.

\subsection{Optimal Algorithm}

The approach is based on an optimal algorithm (see Figure 3), specifically Greedy, that at each step chooses the most suitable piece of the solution based on one or more criteria (multicriteria decision analysis).

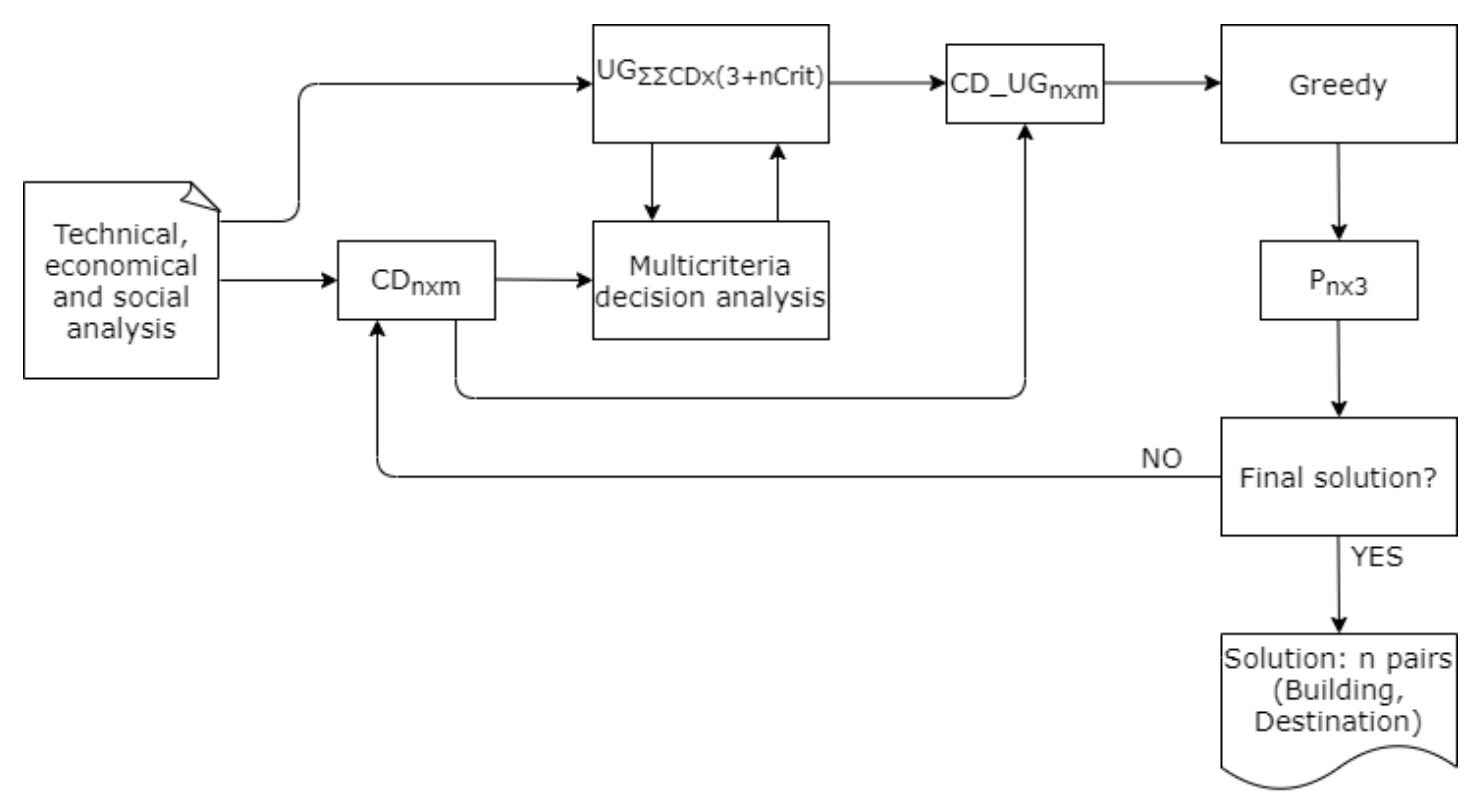

Figure 3. Algorithm block diagram. 
The algorithm from Figure 1 works for a known number of buildings $(n)$ for which a destination is chosen from the $m$ ones available based on a binary matrix of possible correspondences between buildings and destinations ( $C D$ matrix of size $(n \times m))$.

The choice of destination for each building takes into account a series of criteria coded in the UG matrix and in the Coef and Crit vectors, as described below:

The UG matrix has a number of lines equal to the sum of the elements from the $C D$ matrix, namely the total number of Building-Destination correspondences. The first two columns contain all these building-destination possible pairs, in the form of building number-destination number. The following columns contain numerical values specific to all the $n$ Crit dedicated selection criteria. To this is added a last column in which the global utility in the context of the considered criteria is calculated using the multicriteria selection analysis method. The two additional vectors are used to calculate these values. Thus, the Coef vector contains the $n$ Crit coefficients of importance related to the considered criteria. The Crit vector is a binary vector in which a minimum criterion was encoded by 0 and a maximum criterion by 1 .

After calculating the last column of the $U G$ matrix, a $C D \_U G$ matrix was constructed, similar to the $C D$ matrix, except that instead of the values of 1 in the $C D$, in $C D \_U G$ we have the calculated global utilities values. With the global utilities for each of the possible destinations for a building, we can select, using a Greedy approach for each building, the destination that has the maximum global utility.

Thus, we will form a solution matrix $P$ with a number of lines equal to the number of buildings and at least two columns. The first column contains the index of the destination that has the maximum overall utility, the second column contains the value of the maximum global utility. The extra columns are flags for the imposed constraints, if any. If there are any constraints imposed, the solution has to be validated against these constraints. If the solution does not meet them, the algorithm is resumed until the suited solution is obtained.

Given the optimal algorithm quality of both the Greedy algorithm and the multicriteria selection methods, the algorithm presented above will lead to the optimal solution for the problem and has complexity of the order $n \times(n-1)$, where $n$ is equal to the number of buildings. The variables for the algorithm are presented in Table 2.

Table 2. Variables for the proposed algorithm.

\begin{tabular}{cccc}
\hline Name & Data Type & Dimension & Description \\
\hline$n$ & Integer/Input & Scalar & Number of buildings \\
$m$ & Integer/Input & Scalar & Number of possible destinations for the buildings \\
$C D$ & Integer (bool)/Input & $n \times m$ & Matrix of correspondences between buildings and destinations \\
$U G$ & Real/Input and Computed & $n U G \times(3+n C r i t)$ & Matrix of multicriteria selection \\
$n U G$ & Integer/Computed & Scalar & Number of lines in UG \\
$C D \_U G$ & Real/Computed & $n \times m$ & Support matrix \\
Coef & Real/Input & $n C r i t$ & Importance coefficients for each criterium \\
Crit & Integer (bool)/Input & $n C r i t$ & Criterium type \\
$n C r i t$ & Integer/Input & Scalar & Number of criteria \\
$n C o n$ & Integer/Input & Scalar & Number of constraints for solution \\
$P$ & Real/Output & $n \times(2+n C o n)$ & Solution matrix \\
\hline
\end{tabular}

\subsection{Objective of the Algorithm}

The objective is to determine the optimal allocation of possible destinations for existing buildings within a post-industrial site taking into account any criteria considered relevant for the transition to IHT development, as well as a number of location-related constraints.

First $n$ existing buildings and $\mathrm{m}$ possible destinations for them are identified. The coding of correspondences between buildings and destinations is done binary in the $C D$ matrix, the matrix of $(n \times m)$ dimension $(0=$ in building $i$ cannot be destination $j ; 1=$ in building $i$ can be destination $j)$. 
The matrix $U G$ for applying the multicriteria selection is constructed from the $C D$ matrix as follows:

$$
\left.\begin{array}{l}
U G(i i, 1)=i \\
U G(i i, 2)=j
\end{array}\right\} \quad \text { if } \quad C D(i, j)=1
$$

The quantifications resulting from the specialized studies for the chosen $n$ Crit criteria are completed in the following columns from the $U G$ matrix:

$$
U G(i i, 2+j j)=\text { value for the } j j \text { criterion }
$$

In the last column of the $U G$ matrix, the value related to the multicriteria selection is calculated:

$$
U G(i i, 3+n C r i t)=\text { value of the computed acquired utility }
$$

For each building $i$ from 1 to $n$ we compute:

$$
\begin{gathered}
\max _{i}=\max _{k \in\{U G(k, 1)=i\}} U G(k, 2+y) \\
\min _{i}=\min _{k \in\{U G(k, 1)=i\}} U G(k, 2+y) \\
n e f_{i}=\operatorname{Crit}(y) * \min _{k \in\{U G(k, 1)=i\}} U G(k, 2+y)+(1-\operatorname{Crit}(y)) * \max _{k \in\{U G(k, 1)=i\}} U G(k, 2+y)
\end{gathered}
$$

where: $y=$ criterion number (from 1 to $n C$ rit).

$$
\begin{aligned}
U G(x, 3+n \text { Crit }) & \\
& =\sum_{y=1}^{n C r i t} \operatorname{Coef}(y) \\
& *\left\{\begin{array}{r}
\frac{\mid U G(x, 2+y)-n e f(U G(x, 1)}{\max _{U G(x, 1)}-\min _{U G(x, 1)},}, \text { if } \max _{U G(x, 1)} \neq \min _{U G(x, 1)}, \text { if } \max _{U G(x, 1)}=\min _{U G(x, 1)}
\end{array}\right.
\end{aligned}
$$

computed for $x$ from 1 to $n U G$.

The importance coefficients for each criterion are established in the Coef matrix and the type of each criterion $(0=$ minimum; $1=$ maximum $)$ in the Crit matrix. Both have a number of $n C r i t$ elements.

Thus, the $U G$ matrix will have $(3+n C r i t)$ columns and $n U G$ lines:

$$
n U G=\sum_{i=1}^{n} \sum_{j=1}^{m} C D(i, j)
$$

Then, it is completed a support matrix $C D \_U G$ for the application of the optimal selection Greedy algorithm. This is a matrix similar to $C D$, having instead of $1 \mathrm{~s}$, the computed acquired utility corresponding to destination $j$ for the building $i$ :

$$
\text { CD_UG(UG(ii,1),UG(ii,2)) =UG(ii,3 + nCrit })
$$

computed for $i$ from 1 to $n U G$. The remaining of $C D_{-} U G$ is filled with $0 \mathrm{~s}$. The solution built in the solution matrix $P$ is the following:

$$
\begin{gathered}
P(i, 1)=\operatorname{index}\left(\max _{j=1, m} C D_{U G(i, j)}\right)-\text { destination } \\
P(i, 2)=\max _{j=\overline{1, m}} C D \_U G(i, j)-\text { computed acquired utility }
\end{gathered}
$$




\subsection{Constraints}

If there are constraints on the solution, they are coded in one or more additional columns, $n$ Con, in the $P$ matrix to be used in the solution validation step.

Thus, if, for example, the unique choice of each destination is required, the constraint will be coded in the third column of the $P$ matrix by a scaling factor related to the single choice.

$$
P(i, 3)=1+9 * i n t\left(\frac{1}{\sum_{j=1}^{m} C D(i, j)}\right) \text { - uniqueness }
$$

\subsection{Solution Approach}

In Figure 4 is presented the methodological framework for the optimal selection of destinations for a number of buildings from a post-industrial site.

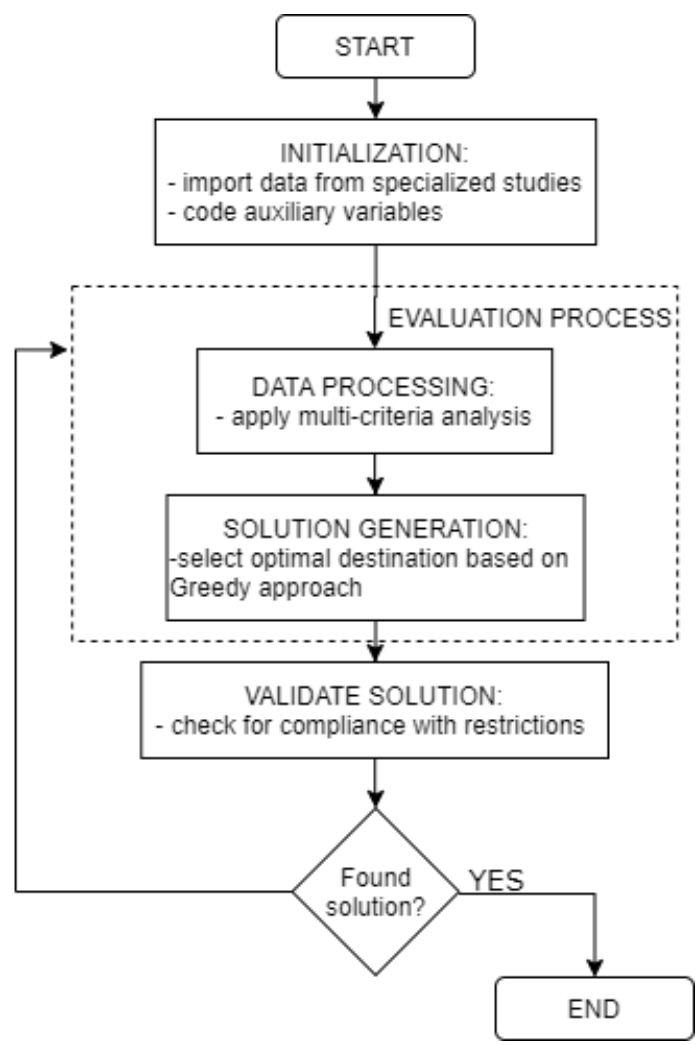

Figure 4. Methodological framework.

\subsubsection{Initialization}

The perimeter under study is identified. Within the perimeter, the existing viable buildings are catalogued and evaluated. Based on the specialized studies, the selection criteria are established, the possible destinations and the quantification corresponding to each criterion for the pairs (building, destination) is performed.

For example, in a technical-economic study, the evaluation criteria of the buildings are established, resulting in the possible destinations and the quantification related to the criteria. Moreover, if we refer to the involvement of the community, it is necessary to carry out a sociological study based on which the sociological criteria of the type of positive/negative effects of the development of tourism in the analyzed area are established. 


\subsubsection{Evaluation Process}

The data evaluation process in order to obtain a solution contains two stages of optimization. In the first stage, a processing of the resulting data is performed for the considered criteria using a multicriteria decision method (Figure 5). In the second stage, a choice of destinations is made using an optimal Greedy approach based on the values resulting in the multicriteria decision stage. In this way, an optimal choice of destinations is ensured taking into account all the established criteria, resulting in a candidate solution (Figure 6).

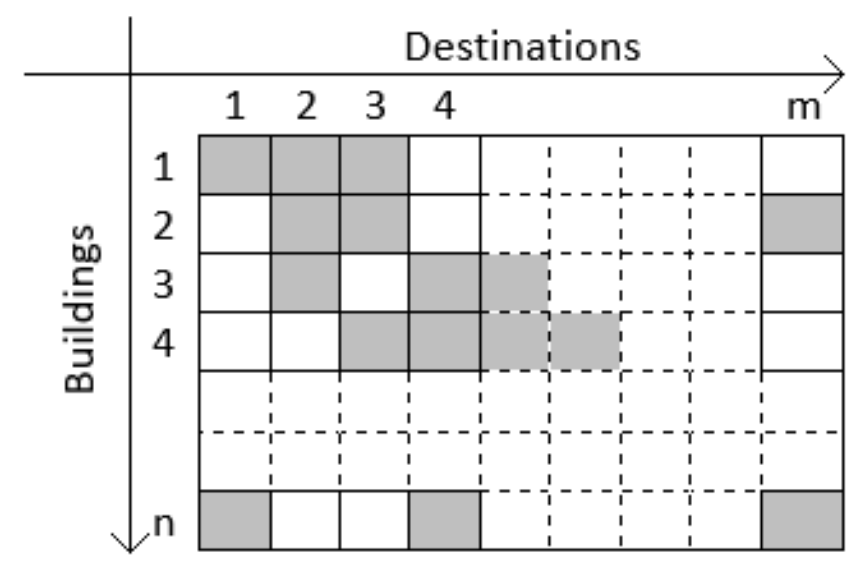

Figure 5. First stage evaluation results.

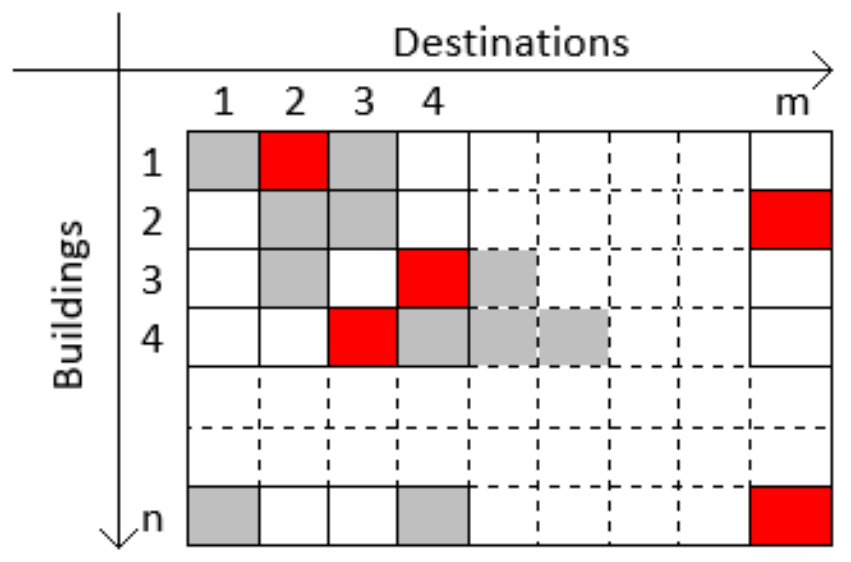

Figure 6. Second stage evaluation results.

\subsubsection{Validate Solution}

The validation of the candidate solution is done based on the restrictions imposed by the analyzed case, if any.

For example, an imposed restriction could be to test the uniqueness of the choice of destinations (Figure 7). If we have repetitions of a destination, a Greedy approach is applied, choosing to keep in solution the destination with the greatest importance in the selection and a new iteration is made to choose a new candidate solution that takes into account the criteria and restrictions imposed. 


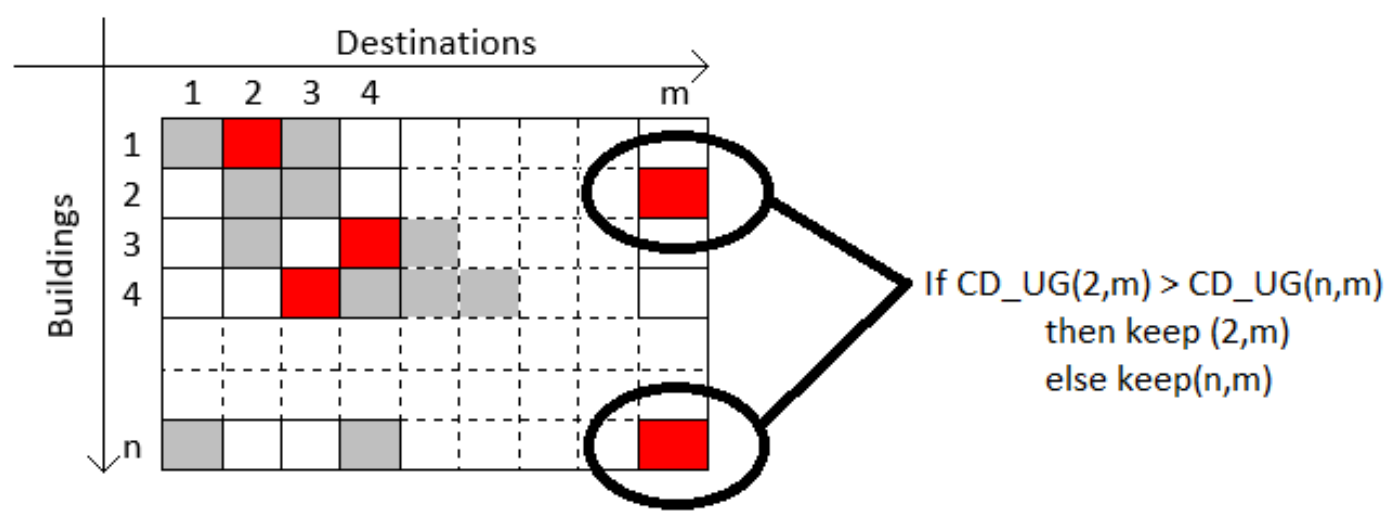

Figure 7. Uniqueness of the choice validation.

\section{Valorization of the Petrila's Post-Industrial Heritage}

\subsection{Preliminary Studies}

4.1.1. Technical-Economic Study Regarding the Choice of Possible Destinations of the Buildings that Will Be Part of the Theme Park

Contemporary society requires the promotion of economic activities to integrate environmental and social concerns, in order to produce an authentic and sustainable development over time. Romania's mining industry has experienced a serious decline in the last years, going through a major restructuring process. Mining, in particular, is an "anticlinal fold" with legacy of past development decisions, the operation and abandonment of mines being, by their nature, irreversible operations. Each phase of the mining process involves a certain degree of dislocation and disturbance of the land. In the case of many sites, the damage is already existing, in which case the post-project (post-operative) rehabilitation is necessary. These situations are expensive and often it is not known exactly where the necessary funds will come from. The rehabilitation of the affected areas by the mining exploitation must be done efficiently, in terms of cost and with a small budget. Time can become one of the tools of the specialist, which in turn is because what the technology and the sustained care can do in a few months, nature does in a few years, on several active sites. The legal and financial problem of rehabilitation represents the climax of the rehabilitation projects.

The mining redevelopment of the affected surfaces by the mining industry must be regarded as part of the mining activity and can be defined as the methodical modelling of the surfaces used by the mining companies, taking into account the public interests. Through the redevelopment works, the previous economic potentials of the region must be recreated, according to the existing conditions. The mining industry implies a mutual relationship between nature and society, as well as between economy, ecology and social life. In addition to extracting the useful mineral substance, the mining industry is responsible for solving the complex problem of removing its negative effects on the environment. Solving this problem requires the collaboration of specialists from different fields: geology, geotechnics, mining, territorial planning, agronomy, forestry, sociology. Contemporary society requires the promotion of economic activities to integrate environmental and social pursuits, in order to produce authentic development that will become sustainable over time.

The first information regarding the presence of coal deposits in the Jiu Valley, more accurate in the town of Petrila, dates back to 1855 when the first geological explorations (Figure 8) were also made that revealed the existence of coal in the zone, as well as the first studies regarding its quality, continuing with the first mining concession over an area of $135,349.2 \mathrm{~m}^{2}$ on the territory of this locality in 1858; on 1 January 1859, Petrila was officially the first mining perimeter in the Jiu Valley. The sedimentary Jiu Valley bituminous coal basin is part of the group of epi-structural, inter-mountains basins in the Southern Carpathians, being located between the Retezat Mountains and the Sebes Mountains to the North, Parang Mountains to the East and Vulcan Mountains to the South. As form, 
it is a triangular trough (Figure 6), with its peak situated to the west from Campu lui Neag village, and the base consists of the alignment Rascoala-Petrila South. The surface of the coal basin is of $155.57 \mathrm{~km}^{2}$, with a length of $45 \mathrm{~km}$, and a width that varies between $1.5 \mathrm{~km}$ to the west and $9 \mathrm{~km}$ to the east [50].

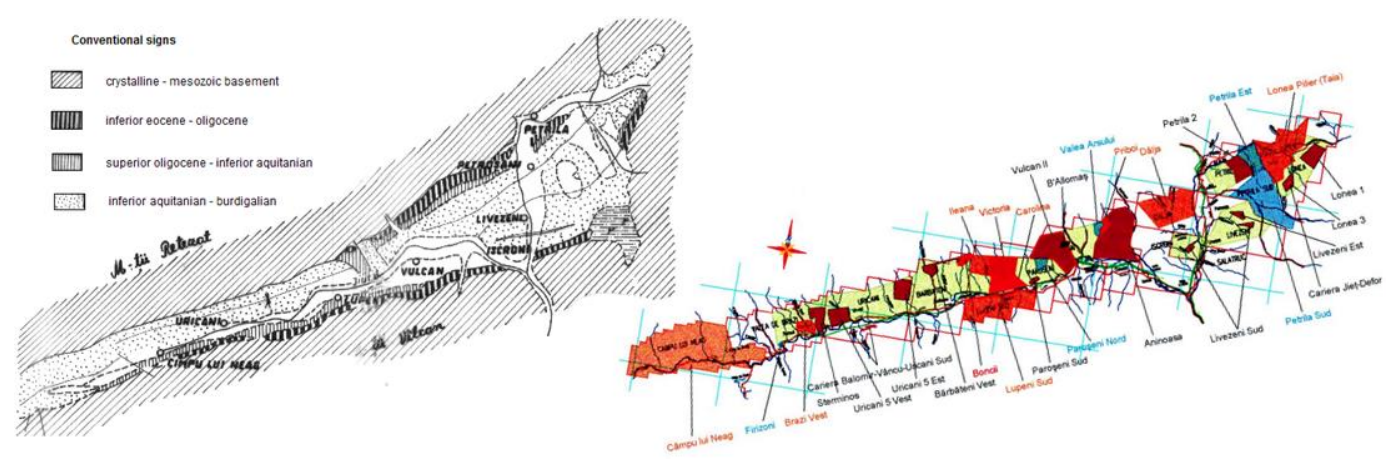

Figure 8. The geological scheme of Petrosani geosyncline (scale 1:200,000) and mining fields delimitation.

Morphologically speaking, it is a region of high hills $(700-800 \mathrm{~m})$, some terraces and alluvial plains. The hills have unregular slopes, either fast, either not, either whole, either disturbed by strong alluvial land. As a position, most of them are orientated NS, but also other orientations exist. The terraces are spread, and can be identified only along the two main valleys of Eastern and Western Jiu rivers. These terraces have small spreads and are sequenced on one or the other side of the valleys that accompany them. Their surface is quite smooth. The alluvial plains are relatively the most spread, especially along the two Jiu Rivers, being characterized by smooth or uneven surfaces. The main hydrographic network of Petrosani geosyncline is made of the two rivers: Western Jiu, which crosses the basin on its length from west to east, and Eastern Jiu, which crosses the geosyncline transversal from north to south.

The Petrila mining perimeter located at the eastern boundary of the Petrosani post tectonic depression, belongs to the northern flank and the axial part of the northern syncline fold from the northeast of the basin. This fold is a syncline with a rounded branch, asymmetrical with the inclined south-southeast axial plane. The northern flank has inclinations of $40-85^{\circ}$, and the southern flank slower, with inclinations of up to $10-30^{\circ}$. The fractures, in their normal majority, of different amplitudes, with openings pronounced by the separation of the homonymous layers along the slope planes, that affect the Petrila perimeter, are predominantly transversal, with inclinations of $70-80^{\circ}$ and the amplitude of (20-150) $\mathrm{m}$. They are accompanied by a system of secondary faults and numerous cracks that have locally affected the deposit. These dislocations divided the Petrila mining perimeter into six tectonic blocks, which in turn fragmented into lenses of different sizes [50].

The study of stratigraphic columns based on results of research drilling, mapping of horizontal mining works (transversal, directional) and geo-mechanical studies related of mining fields from Jiu Valley basin, have shown the existence of a wide variety of sedimentary rocks that have been classified into five main and distinct categories: sandstones category, clays category, marls category, marl-limestones category and microconglomerates category and the varieties of these types. Therefore, in the geo-mechanical context, the rock massif-Jiu Valley sedimentary basin-is a stratified rock massif, consisting of a succession of highly diversified layers of variable thickness (from centimetres to several meters order), which sedimentological gives them a dense structure. Based on such findings, it can be said with certainty that, in geo-mechanical terms, the rock massif is a rock massif of discontinuous inhomogeneity [50].

As opening mining works, we specify: 7 vertical shaft from surface located in the deposit bottom, three underground shaft blind wells through which the descent was made in depth. Vertical partitioning was performed through by horizon works (transversal and directional galleries). The height of the stage was $50 \mathrm{~m}$, starting with the horizon +250 , (block 0) and ending with the horizon -250 (block II) 
located in the axis of the syncline, where the depth from the surface is $895 \mathrm{~m}$. The connection between the horizons was ensured by underground shafts, vertical shafts, inclined shafts and inclined planes. In 2015, when the Petrila mine was officially closed, the underground works were performed at a depth of $940 \mathrm{~m}$; at that time it was the deepest mine in Romania.

Chronologically, the history of coal mining at Petrila is presented in Figures 9 and 10.

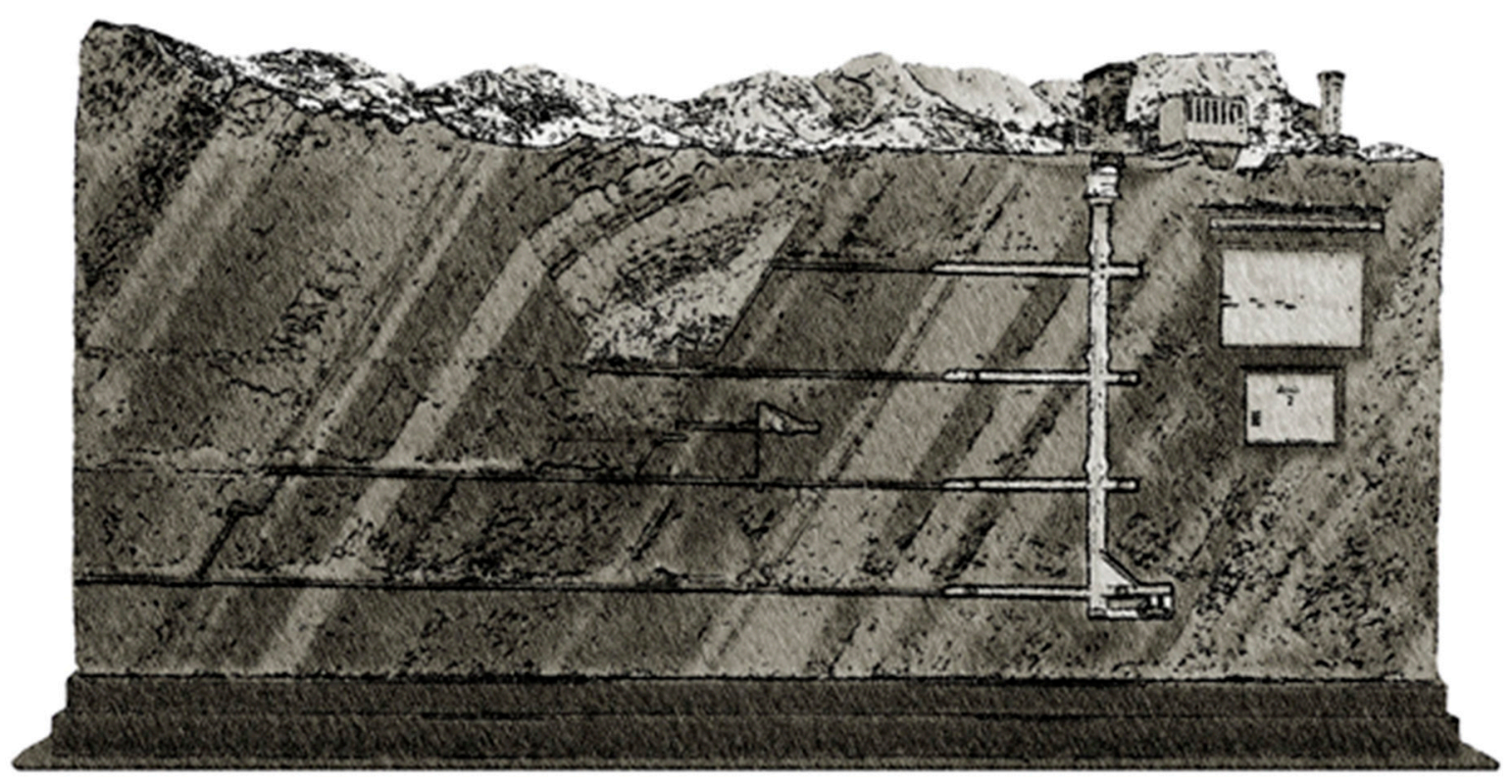

Figure 9. Outline of the opening, preparation and exploitation works of the coal deposit from Petrila.

The extractive field has a major impact on the environment by the discharge of contaminated water from the dumps, tailing dumps and plants for the preparation of useful mineral substances, the instability of the lands that can lead to landslides, fails and subsidence, as well as the dynamics of the affected land surfaces by mining activities. Therefore, an important stage in the elaboration and implementation of a project of rehabilitation and reuse of these perimeters consists in the stability analysis of the underground works and the constructions from the surface, respectively an analysis of the overall stability of the site. As the production activity ceased at the end of 2015, the mine entered the closure stage, in which the underground works were stabilized and the required works to protect both the underground and the surface objectives were executed. The closure of the underground space consisted mainly of embankment works, filling works and watertight insulation works of concrete or masonry, resistant in time, respecting the shape and dimensions of the mining works profiles; the technology for the execution of the concrete isolation dams has been adapted to the concrete working conditions and location of the mining works. The closure of the mining works by filling was performed if the distance between the surface and the underground mining works was less than $50 \mathrm{~m}$ or if abandoning them could have affected the stability of the surface. In most cases, the filling of the galleries, apart from the fact that it reduces the subsidence of the land, also presents the advantage of the storage of non-toxic mining waste. For the filling, the hydraulic or pneumatic filling was applied, depending on the conditions or with dry filling, the latter reducing the closure costs. 


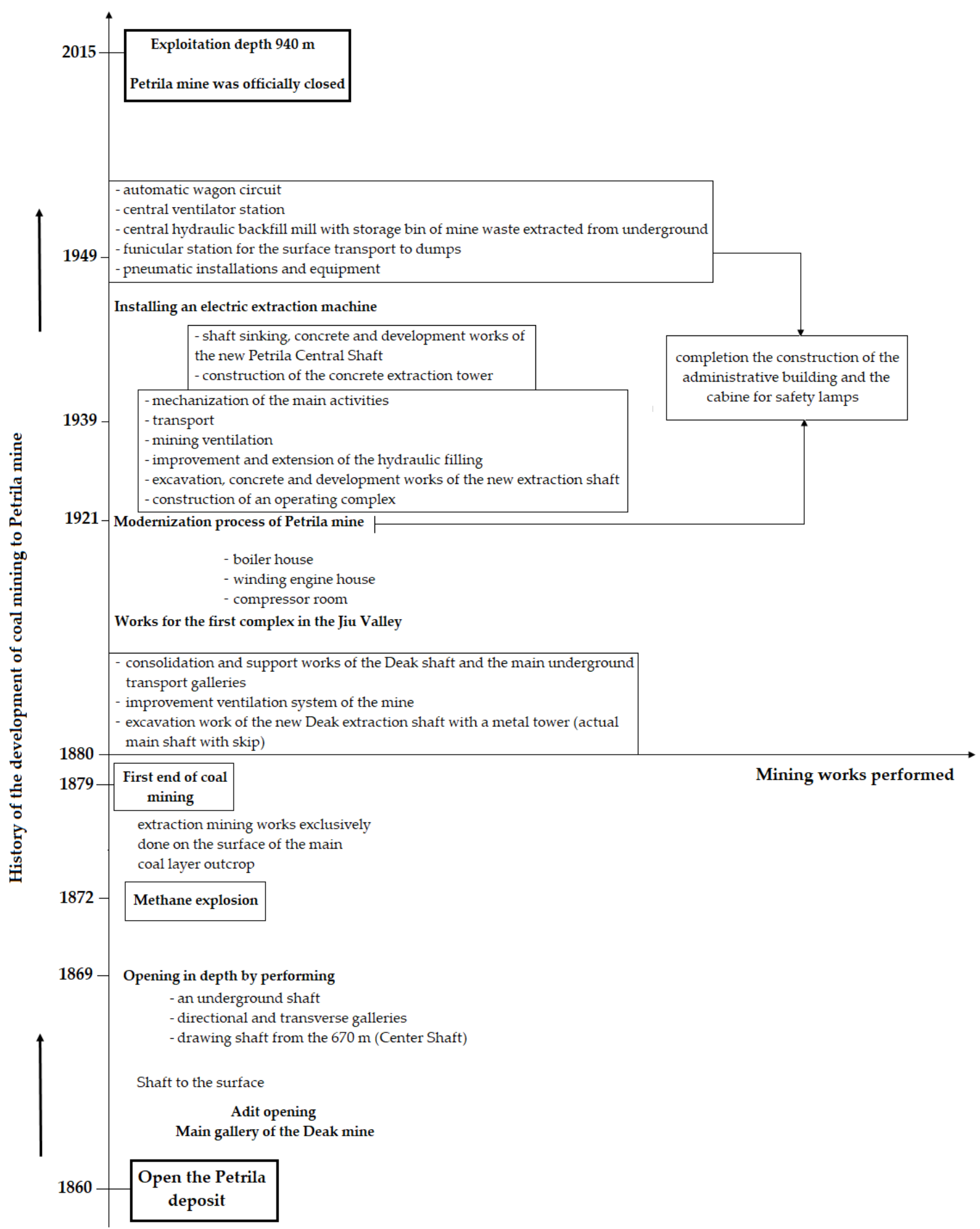

Figure 10. History of the development of coal mining to Petrila mine and the corresponding mining works performed.

Where, following the studies and observations made, the existence of cracks in the outline of the works and/or in the surrounding rock was found, in order to prevent an uncontrolled migration of water (or even gases) to the isolated space, consolidation and sealing works of the supports and surrounding rocks have been carried out, by injecting under a certain pressure of substances that have the capacity to penetrate in the cracks and reinforce them, forming a consolidated rocks shield with superior mechanical strength. Since the mine has been classified as a fiery mine, after the mine closure, it is compulsory to monitor any potential leakage or spontaneous occurrences of gases, especially methane. 
The monitoring is done through a firedamp detector station by staff trained and certified by INSEMEX Petroşani. The mine water was planned to be collected in the micro station basin of pumps from the transversal gallery at the level of the horizon where the process of depositing solid suspensions takes place and from there the water is discharged to the surface in the basin of the compressor station. As the technological process in the underground has ceased, there is no possibility of pollution of groundwater. In the mine water evacuation route, no closed mining works were identified that could be flooded. The closure of the vertical mining works (shafts, inclined shafts, ventilation channels), was accomplished by filling them with backfill material from the waste dumps class $4 \mathrm{~B}$. In the case of shafts with access to the surface, the last $50 \mathrm{~m}$ (the upper part of the shaft-towards the shaft collar) were filled with $4 \mathrm{~A}$ class material, which does not present a tendency to form vaults, consisting of non-corrosive, running ground, brittle, insoluble materials in water, with particle size below $100 \mathrm{~mm}$. The shafts and all vertical mining works were backfilled to the surface or to the proposed site for fixing the cement plug. After the completion of the filling works of the shafts, they were monitored to follow the settlement of the filling column, in order to ensure the stability of the vertical mining works in particular, and the general stability of the site in general. After the closing works were carried out, the used equipment was recovered and transported to the surface, following a precise order, to avoid their deterioration and to prevent accidents. From the information made available by the personnel currently serving the monitoring works of the underground mining works stability, the conclusion is that these works are stable and there is no danger of affecting the stability of the surface area, respectively of the constructions located in the perimeter that is the study object of this paper.

The constructions located on the surface were designed in such a way so that they dispose of a high load-bearing capacity throughout the mine's exploitation period, but also after its depletion. From this point of view, we considered that these industrial structures may have potential for exploitation in the future. In addition to the economic potential of reuse of these constructions, some of them also have a patrimonial value, being included in the industrial patrimony. Starting from the problem approached in this study, we present briefly the existing situation in this moment at Petrila mine, the future destination of each construction and the required works to be performed for the proposed aim; the site is expending on a surface of approximately 13 ha (see Figure 11 and Table 3).

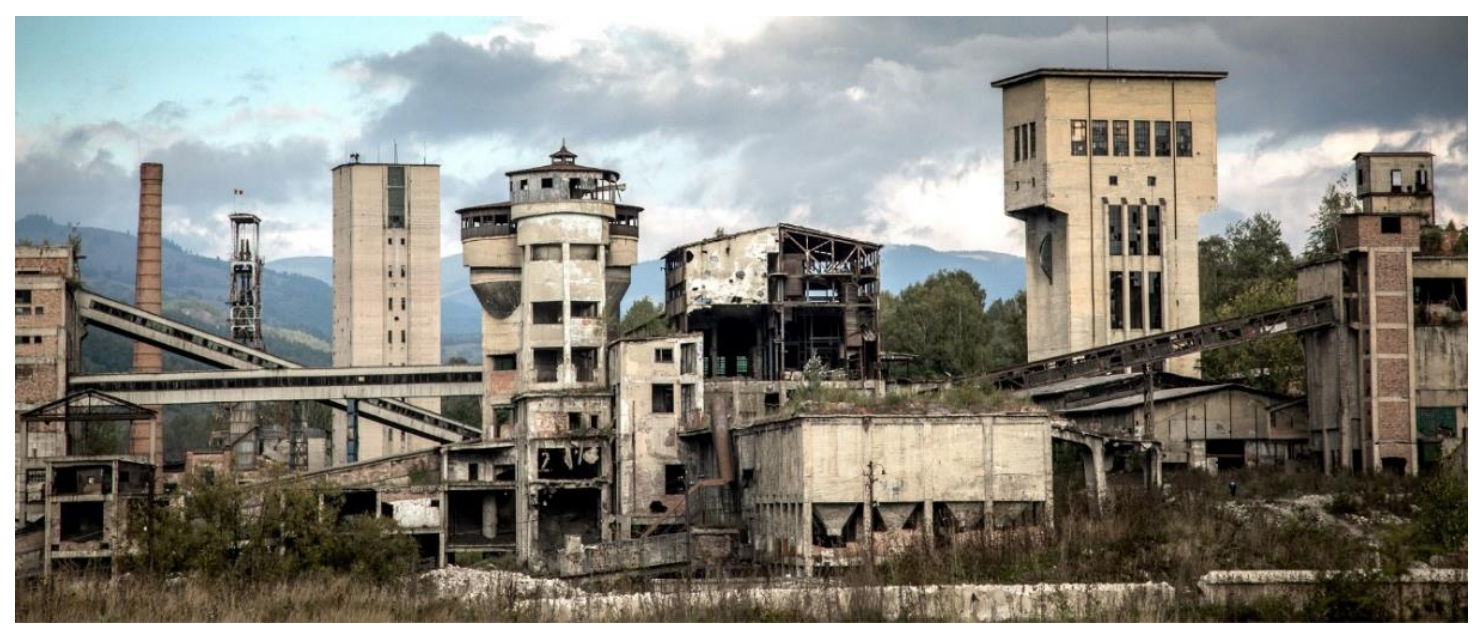

Figure 11. The real situation of the constructions in the mining perimeter of Petrila. 
Table 3. Existing and proposed constructions for rehabilitation with potential for future exploitation.

\begin{tabular}{|c|c|c|c|c|c|c|c|c|}
\hline Existing Buildings & Symbol & Destination & Symbol & Required Works & Outgoing (Euro) & Area $\left(\mathrm{m}^{2}\right)$ & Unit Costs (Euro/m $\mathrm{m}^{2}$ ) & Time (Days) \\
\hline \multirow{6}{*}{ Dispensary } & \multirow{6}{*}{ B1 } & \multirow{2}{*}{ Exhibition/presentation space } & \multirow{2}{*}{ D1 } & consolidation & 21,000 & 51 & 411.76 & 5 \\
\hline & & & & redevelopment & 60,000 & 210 & 285.71 & 20 \\
\hline & & \multirow{2}{*}{ Cafeteria } & \multirow{2}{*}{ D2 } & consolidation & 21,000 & 51 & 411.76 & 5 \\
\hline & & & & redevelopment & 75,000 & 210 & 357.14 & 30 \\
\hline & & \multirow{2}{*}{ Shop } & \multirow{2}{*}{ D3 } & consolidation & 21,000 & 51 & 411.76 & 5 \\
\hline & & & & redevelopment & 55,000 & 210 & 261.9 & 12 \\
\hline \multirow{10}{*}{$\begin{array}{l}\text { Main building (current } \\
\text { administrative space) }\end{array}$} & \multirow{10}{*}{ B2 } & \multirow{2}{*}{ Entertainment space } & \multirow{2}{*}{ D4 } & consolidation & 85,000 & 180 & 472.22 & 10 \\
\hline & & & & redevelopment & 510,000 & 2000 & 255 & 48 \\
\hline & & \multirow{2}{*}{ Shop/store } & \multirow{2}{*}{ D3 } & consolidation & 85,000 & 180 & 472.22 & 10 \\
\hline & & & & redevelopment & 770,000 & 2000 & 385 & 28 \\
\hline & & \multirow{2}{*}{ Restaurant } & \multirow{2}{*}{ D5 } & consolidation & 85,000 & 180 & 472.22 & 10 \\
\hline & & & & redevelopment & 874,000 & 2000 & 437 & 25 \\
\hline & & \multirow{2}{*}{ Cinema } & \multirow{2}{*}{ D6 } & consolidation & 85,000 & 180 & 472.22 & 10 \\
\hline & & & & redevelopment & 850,000 & 2000 & 425 & 23 \\
\hline & & \multirow{2}{*}{ Museum } & \multirow{2}{*}{ D7 } & consolidation & 45,000 & 180 & 250 & 10 \\
\hline & & & & redevelopment & 650,000 & 2000 & 325 & 26 \\
\hline \multirow{4}{*}{$\begin{array}{l}\text { Building near the } \\
\text { school mine }\end{array}$} & \multirow{4}{*}{ B3 } & \multirow{2}{*}{ Conference room } & \multirow{2}{*}{ D8 } & consolidation & 20,000 & 105 & 190.48 & 9 \\
\hline & & & & redevelopment & 65,000 & 600 & 108.33 & 14 \\
\hline & & \multirow{2}{*}{ Education space } & \multirow{2}{*}{ D9 } & consolidation & 20,000 & 105 & 190.48 & 9 \\
\hline & & & & redevelopment & 75,000 & 600 & 125 & 14 \\
\hline
\end{tabular}


Table 3. Cont.

\begin{tabular}{|c|c|c|c|c|c|c|c|c|}
\hline Existing Buildings & Symbol & Destination & Symbol & Required Works & Outgoing (Euro) & Area $\left(m^{2}\right)$ & Unit Costs (Euro/m²) & Time (Days) \\
\hline \multirow{2}{*}{ School Mine } & \multirow{2}{*}{ B4 } & Mine museum & D10 & redevelopment & 42,000 & 450 & 93.33 & 7 \\
\hline & & Education space & D9 & redevelopment & 44,000 & 450 & 97.78 & 7 \\
\hline \multirow{4}{*}{ Mechanical workshop } & \multirow{4}{*}{ B5 } & \multirow{2}{*}{ Mechanical workshop museum } & \multirow{2}{*}{ D11 } & consolidation & 39,000 & 560 & 69.64 & 8 \\
\hline & & & & redevelopment & 90,000 & 1400 & 64.29 & 12 \\
\hline & & \multirow{2}{*}{ Education space } & \multirow{2}{*}{ D9 } & consolidation & 39,000 & 560 & 69.64 & 8 \\
\hline & & & & redevelopment & 110,000 & 1400 & 78.57 & 15 \\
\hline \multirow{2}{*}{ Shaft with Skip } & \multirow{2}{*}{ B6 } & \multirow{2}{*}{ Shaft with Skip museum } & \multirow{2}{*}{ D12 } & consolidation & 160,000 & 157 & 1019.11 & 25 \\
\hline & & & & redevelopment & $1,500,000$ & 785 & 1910.83 & 80 \\
\hline \multirow{6}{*}{ Center shaft with tower } & \multirow{6}{*}{ B7 } & \multirow{2}{*}{ Centre Shaft museum } & \multirow{2}{*}{ D13 } & consolidation & 190,000 & 157 & 1210.2 & 30 \\
\hline & & & & redevelopment & $2,200,000$ & 785 & 2802.55 & 90 \\
\hline & & \multirow{2}{*}{ Centre Shaft museum + restaurant } & \multirow{2}{*}{ D14 } & consolidation & 190,000 & 157 & 1210.2 & 30 \\
\hline & & & & redevelopment & $2,600,000$ & 785 & 3312.12 & 105 \\
\hline & & \multirow{2}{*}{ Centre Shaft museum + education space } & \multirow{2}{*}{ D15 } & consolidation & 190,000 & 157 & 1210.2 & 30 \\
\hline & & & & redevelopment & $2,750,000$ & 785 & 3503.19 & 110 \\
\hline
\end{tabular}


The shafts and extraction equipment are characterized by a long period of continuous operation, being the first works that are performed at the opening, and consequently, the last works that are abandoned at the closing of mine. With component parts located over long distances on independent foundations, extraction equipment may suffer deformation due to mechanical stress or movements of the ground. The foundations of the tower are of monolithic concrete, and the fixing of the tower and the counter-excavation was made by metal screws for the foundation. The counter-excavation of the tower is a sloping metal construction, which at the top is linked to the tower, and at the bottom it is supported by the legs on two independent concrete foundations.

The shafts were included in the closure program, therefore, the stabilization and refilling works were carried out, so that the costs related to the closure are not included in the consolidation one. Here, the consolidation and rehabilitation include the works that will be carried out on the surface, on the height of $50 \mathrm{~m}$ (works of concrete and redevelopment of the interior space).

The part of buildings involves the consolidation works of the foundations and the external surfaces, respectively, the redevelopment works of the interior space for the purpose in which they are foreseen by the project of social and economic development of the site. For all constructions, maintenance work will be carried out over the entire period of future exploitation of the site.

\subsubsection{Residents' Attitude towards IHT Development}

The purpose of the study is to determine the attitude of the locals regarding the development of industrial tourism in the Petrila area, having as outputs the answers to the following research questions: (1) do the inhabitants want the IHT development? (2) what would be the economic, social and environmental effects from the perspective of the inhabitants related to the IHT development? (3) what is the opinion of the locals regarding the choice of destinations for the identified buildings?

The study [51], caried out on the case of Las Medulas gold mines from Spain, analyzes the support of the inhabitants and the impact they perceive, in order to have an active implication of the locals, who otherwise could hinder the comprehensive planning of tourism. The active involvement of the community would generate the so-called "resident responsive tourism" that, when implemented successfully, may in turn have a favorable influence on the attitude of that community [52]. This reasoning explains the particular relevance of the attitudes of the locals towards the tourist activity, considered [53] to be the main factor when predicting the choice of the destination of the visitor [54], the main objective in the development of tourism is to maximize the positive effects on the host community, while reducing the negative ones [55]. Ref. [56], as the perception and attitude of the local population towards the development of tourism plays a key role in shaping urban revitalization [57].

The main reason this topic is analyzed with interest is that the perception and attitude of an area inhabitants towards the IHT development can be constituted as part of the strategy of development of tourism projects taking into account the CBT development. For tourism activity in an area to become prosperous, its negative effects need to be minimized, so that the development of tourism-specific activities will be perceived favorably by the local population in the host community. Ref. [58] noticed that in many less developed regions of the world, the locals' opposition to tourism development is likely to increase due to poor management of unforeseen effects of tourism development, which would lead to loss of potential economic benefits.

In developing and engaging with CBT, the goal is to achieve results that will lead to a balance between benefits and costs for both residents and tourism stakeholders. Thus, the inhabitants evaluate tourism in terms of social exchange [59-62], that is, they evaluate it in terms of benefits or expected costs obtained in exchange for the services provided.

In order to reach the research purpose, namely, to determine the attitude of the locals regarding the development of industrial tourism in the Petrila area in Jiu Valley the model proposed in [63] and taken up in [64] was used. The model tests the relationships between the perception of the inhabitants on the impact of tourism, their availability to support the development of tourism, the necessary restrictions in the tourism development efforts as well as the support granted in order to achieve this goal. 
The research started with a quantitative method-a questionnaires-based survey applied to the inhabitants of Petrila [65]. The results show that from a number of 1.773 questionnaires submitted, a total of 1.404 questionnaires were completed and validated, having among respondents $51.2 \%$ females and $48.8 \%$ males all over 18 years old. From the respondents, $46.6 \%$ are employed in the public sector, $16.5 \%$ in the private sector, $5.3 \%$ have their own business, $2.3 \%$ are unemployed, $0.8 \%$ households, $0.8 \%$ retirees and $27.8 \%$ students, $77.4 \%$ of them have lived in the Petrila area for over 20 years. This sampling resulted as statistically representative of the population of the town, with a marginal error of $\pm 5 \%$.

From the five sections of the questionnaire [64], using Likert scale (from $1=$ "Total disagree" to $5=$ "Total agree"), the impact of tourism development on the economy, the social and cultural influence and the impact on the environment were determined, and the impact on the general satisfaction of the community as well as the attitude of the inhabitants towards additional tourism development in the Petrila area were estimated. So, the model was developed on nine hypotheses [63], represented by the relationships between the five latent constructs: the individual benefits obtained from tourism development (IBTD), the positive effects generated by tourism development (PETD), the negative effects generated by tourism development (NETD), the general satisfaction of the community as a result of tourism development (GSC) and the attitude of the inhabitants toward tourism development (IATD). In each hypothesized relationship an effect can be identified, either positive (+) or negative (-).

Data analysis was performed in two phases, using SPSS 20 and AMOS 18. The reliability analysis considered: the scales for determining the perception of the locals in relation to the effects generated by the development of tourism and the scales for determining the general satisfaction of the community obtained through the development of tourism. The scales demonstrate consistency, the Cronbach alpha index value exceeding the tolerated minimum level for each analysed item. The standardized model estimated by AMOS shows that the model is supported with optimal values as follows: $x^{2}=54.116$, $\mathrm{df}=34, p=0.016(p<0.05)$. The goodness-of-fit index (GFI) is acceptable with values over 0.95 and the root-mean square error (RMSE) shows a perfect match with values below 0.05 and an acceptable match with values less than or equal to 0.08 . In this case, the obtained indicators have the following values: $\mathrm{CMIN} / \mathrm{df}=1592 ; \mathrm{GFI}=0.988 ; \mathrm{RMSE}=0.062$. In conclusion, all the results of the analysis support the representativeness of the sample at the population level.

After making the correlations and determining the Spearman coefficients (Table 4) it was observed that hypotheses 1, 2, 4, 5, 6 and 7 are confirmed with $p<0.01$, with a strong association between their variables, and for hypotheses 3 and 8 the null hypothesis is accepted. Furthermore, for hypothesis 9 , the null hypothesis is accepted because, although it shows a relatively significant degree of association, with $p<0.01$, it has the opposite sign (Table 5).

Table 4. Spearman coefficients.

\begin{tabular}{ccccc}
\hline Hypotheses & \multicolumn{2}{c}{ Relationships between Variables } & Correlations \\
\hline H1 & IBTD & $<->$ & PETD & $0.766\left(^{* *}\right)$ \\
H2 & IBTD & $<->$ & GSC & $\left.0.511^{* *}\right)$ \\
H3 & IBTD & $<->$ & NETD & $-0.086\left(^{* * *}\right)$ \\
H4 & IBTD & $<->$ & IATD & $0.769\left(^{* *}\right)$ \\
H5 & PETD & $<->$ & IATD & $0.866\left(^{* *}\right)$ \\
H6 & PETD & $<->$ & GSC & $0.646\left(^{* *}\right)$ \\
H7 & GSC & $<->$ & IATD & $0.857\left(^{* *}\right)$ \\
H8 & NETD & $<->$ & GSC & $0.031\left(^{* * *}\right)$ \\
H9 & NETD & $<->$ & IATD & $0.229\left(^{* * *}\right)$ \\
\hline
\end{tabular}

${ }^{(* *)}$ Significant $<0.01$ (bilateral). $\left.{ }^{* * *}\right)$ Insignificant. 
Table 5. Results of hypothesis testing in AMOS.

\begin{tabular}{ccccc}
\hline Hypotheses & \multicolumn{2}{c}{ Relationships between Variables } & Confirmed/Rejected \\
\hline H1 & IBTD & $(+)$ & PETD & Confirmed \\
H2 & IBTD & $(+)$ & GSC & Confirmed \\
H3 & IBTD & $(-)$ & NETD & Rejected $\left(^{*}\right)$ \\
H4 & IBTD & $(-)$ & IATD & Rejected $\left(^{*}\right)$ \\
H5 & PETD & $(+)$ & IATD & Confirmed \\
H6 & PETD & $(+)$ & GSC & Confirmed \\
H7 & GSC & $(+)$ & IATD & Rejected $\left(^{*}\right)$ \\
H8 & NETD & $(-)$ & GSC & Rejected $\left(^{*}\right)$ \\
H9 & NETD & $(+)$ & IATD & Rejected $(* *)$ \\
\hline
\end{tabular}

$\left({ }^{*}\right)$ Critical report $(\mathrm{CR})<1.96 .\left(^{* *}\right)$ Although critical report $(\mathrm{CR})>1.96$, it has opposite sign.

It turns out that the possible negative effects that could derive from the development of IHT are not influential factors in determining the attitude of the inhabitants of the area. In this sense, all the hypotheses that support the opposite are rejected both after the Spearman correlations and within the structural model. The potential positive effects to be registered following the development of IHT have a major influence in determining a positive attitude among the locals, there being a strong association between the perspective of obtaining benefits at individual level and the perception regarding the positive effects generated by the development of the tourism as well as between the perception regarding the positive effects generated by the development of the tourism and the attitude of the locals in relation to the development of the tourism.

The results provide the right framework for extending the analysis in terms of IHT in the area, by transforming the former Petrila Mine perimeter into a theme park. Visitors will have the opportunity to find out the work that the miners carried out in the past. At the same time, it can be presented, from a historical point of view, what mining meant for the inhabitants of the area, the technological, economic, cultural, demographic and social impact that the activity had on the population and what the activity ceasing meant, but also results of present activities carried out by the inhabitants for maintaining their traditions.

In conclusion, in summary, the results are:

- there is availability to support measures for the development of tourism activities in the area, the attitude of the inhabitants towards the development of tourism being a positive one, most of the answers, $78 \%$, being placed in the "agree" area;

- the idea of integrating the theme park in a tourist circuit generated positive feedback, the greatest openness to the idea being registered at the level of age ranges $28-37$ years with $91 \%$ and $48-57$ years with $89 \%$, their answers being placed in the "total agree" area;

- regarding the positive effects to be generated by the development of tourism activities in the area, most of the respondents are of the opinion that they will not be late to appear, and place the answers in the area "total agree" - "agree" (82\% regarding positive economic effects, $75 \%$ regarding positive social effects and $71 \%$ regarding positive environmental protection effects);

- the negative effects are not expected to appear according to the opinion of the majority of the surveyed population who place the most responses in the "disagree" area (82\% regarding negative economic effects and $78 \%$ regarding negative social effects and $77 \%$ regarding negative environmental protection effects);

- regarding the positive feedback on the development of a theme park in the former Petrila Mine perimeter, most of the answers are placed in the "total agree" area; the respondents who are the most open-minded about this idea are in the 28-37 years age range with $83 \%$ and $48-57$ years with $89 \%$;

- the destinations of the buildings from the heritage list (in accordance with the technical solutions of consolidation and restoration) based on the preferences of the locals are presented in Table 6. 
Table 6. Buildings and destinations.

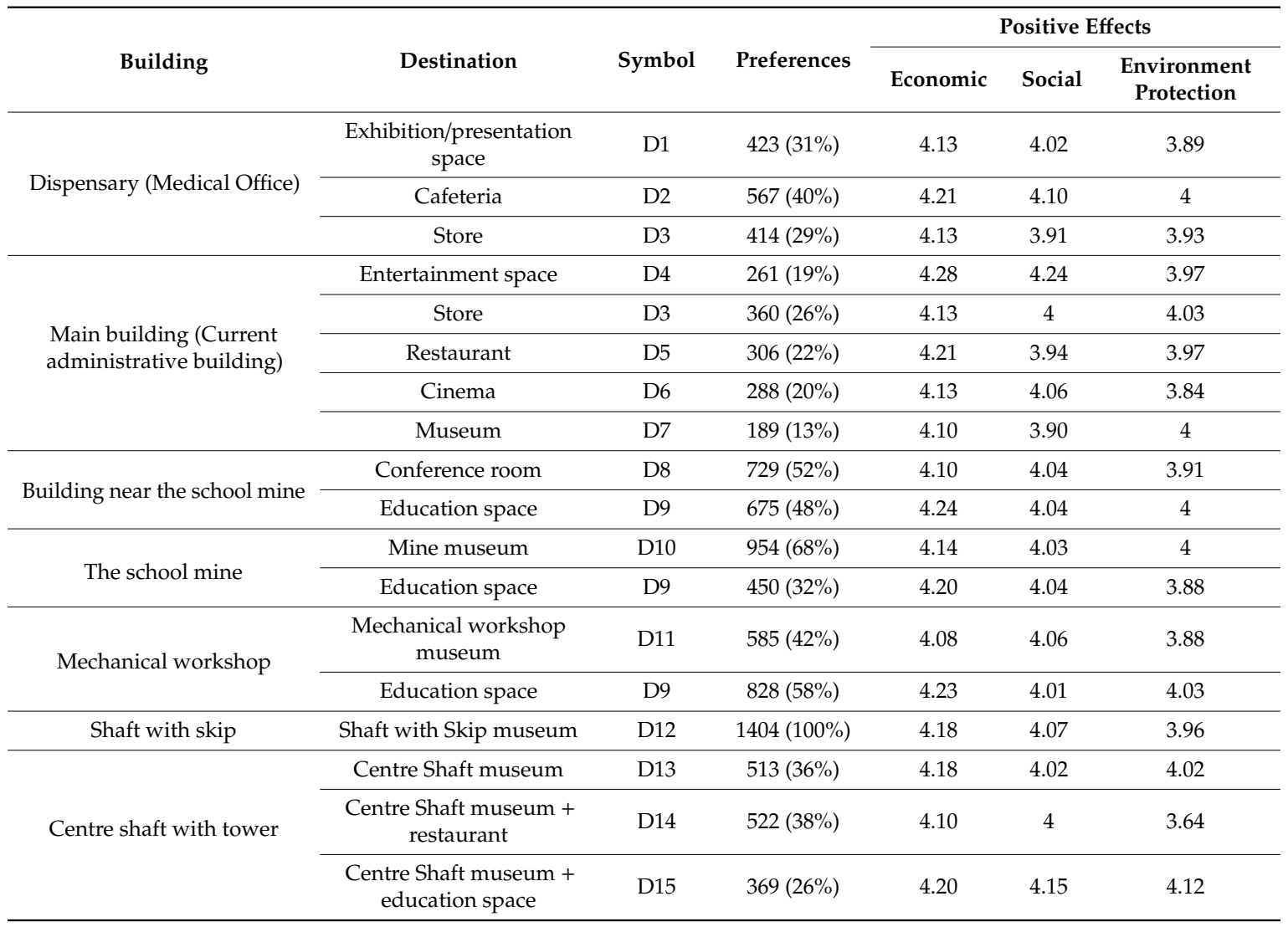

As an example, for the Dispensary building, the choice of destination and the potential effects are presented, after processing the collected data in Figure 12. As can be noticed, of the three options offered, the first option of the respondents is the Cafeteria cumulating $40 \%$ of the answers. This choice is also characterized by good averages regarding the positive effects it will attract, as follows: economic effects— 4.21 , social effects -4.10 and environmental protection effects -4 .

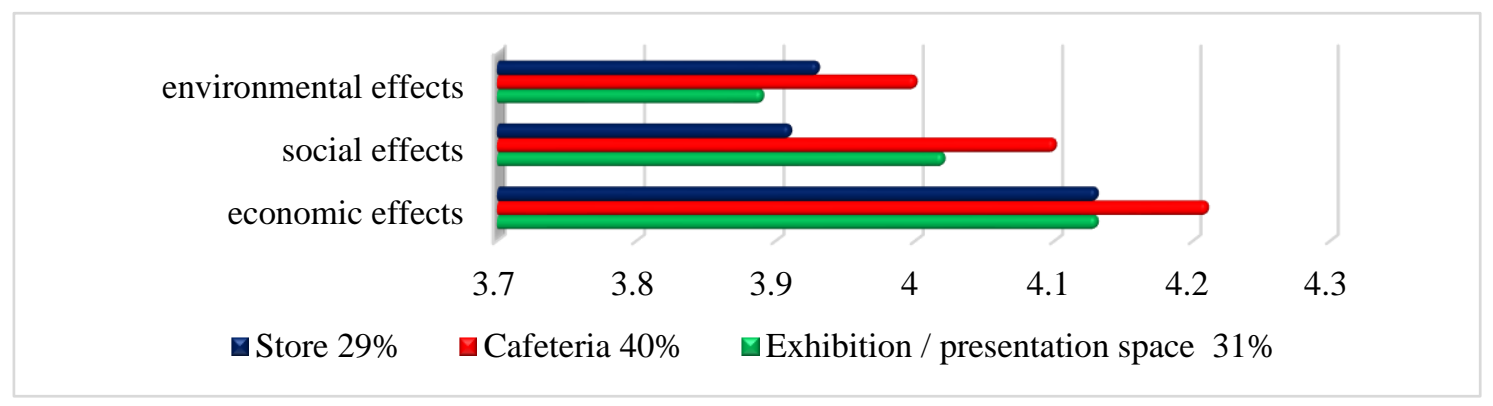

Figure 12. Destination hierarchy for Dispensary.

\subsection{Petrila's Industrial Heritage Case Study}

The algorithm applied from Petrila's industrial heritage valorization started from the existing buildings identified as presented in Figure 13. From these buildings, $n=7$ buildings (B1-B7) were chosen to be part of the theme park. 


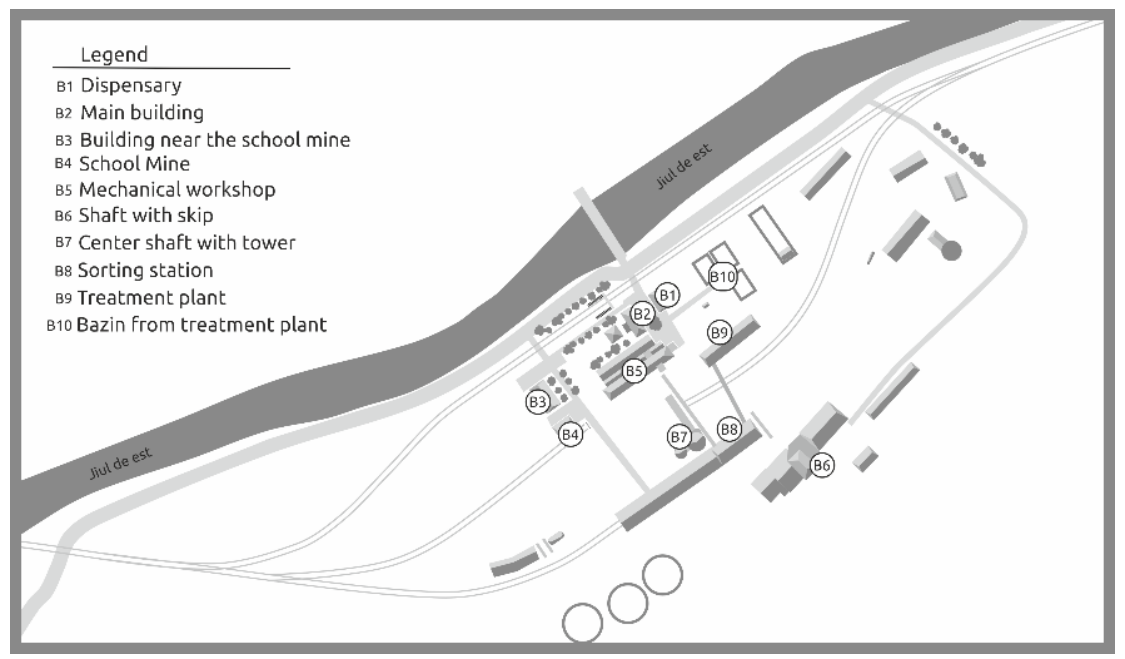

Figure 13. Petrila's industrial heritage buildings map.

The choice of possible destinations for the seven buildings considering the specifics of the area and of the site were determined. There are $\mathrm{m}=15$ possible destinations (Figure 14).

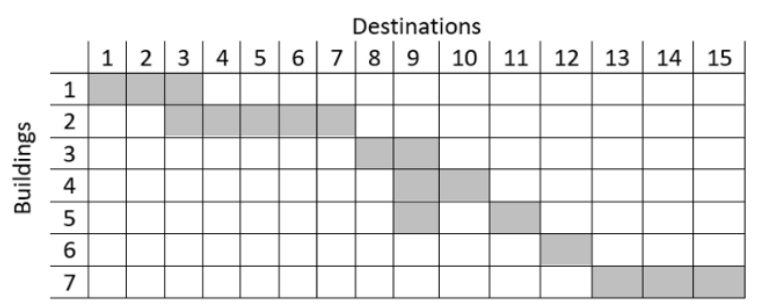

(a)

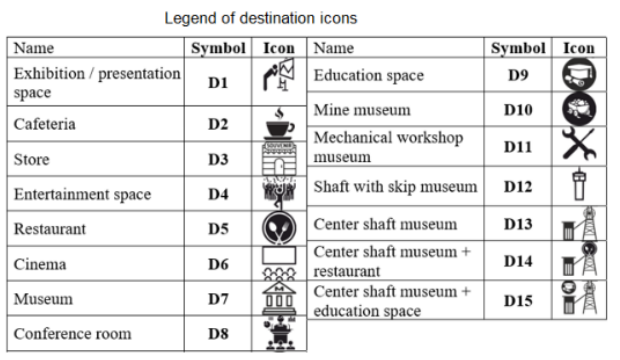

(b)

Figure 14. (a) Buildings-destinations correspondences; (b) Legend of destination icons.

This first study also generated the correspondences between the seven buildings and the possible destinations (Figure 15) resulting in the $C D$ matrix of the form:

$$
C D=\left[\begin{array}{lllllllllllllll}
1 & 1 & 1 & 0 & 0 & 0 & 0 & 0 & 0 & 0 & 0 & 0 & 0 & 0 & 0 \\
0 & 0 & 1 & 1 & 1 & 1 & 1 & 0 & 0 & 0 & 0 & 0 & 0 & 0 & 0 \\
0 & 0 & 0 & 0 & 0 & 0 & 0 & 1 & 1 & 0 & 0 & 0 & 0 & 0 & 0 \\
0 & 0 & 0 & 0 & 0 & 0 & 0 & 0 & 1 & 1 & 0 & 0 & 0 & 0 & 0 \\
0 & 0 & 0 & 0 & 0 & 0 & 0 & 0 & 1 & 0 & 1 & 0 & 0 & 0 & 0 \\
0 & 0 & 0 & 0 & 0 & 0 & 0 & 0 & 0 & 0 & 0 & 1 & 0 & 0 & 0 \\
0 & 0 & 0 & 0 & 0 & 0 & 0 & 0 & 0 & 0 & 0 & 0 & 1 & 1 & 1
\end{array}\right]
$$

A number of 5 criteria were identified according to which to choose the optimal destination for each building. These criteria and the evaluations based on them were established by the two preliminary studies. Thus, there are two technical-economic criteria: consolidation and rehabilitation expenses and execution duration; and three criteria resulting from the sociological study, namely, economic, social and environmental protection positive effects. The resulted matrix $U G$ is: 


$$
U G=\left[\begin{array}{cccccccc}
1 & 1 & 697.47 & 25 & 4.13 & 4.02 & 3.89 & 0 \\
1 & 2 & 768.90 & 35 & 4.21 & 4.10 & 4.00 & 0 \\
1 & 3 & 673.66 & 17 & 4.13 & 3.91 & 3.93 & 0 \\
2 & 3 & 857.22 & 38 & 4.13 & 4.00 & 4.03 & 0 \\
2 & 4 & 727.22 & 58 & 4.28 & 4.24 & 3.97 & 0 \\
2 & 5 & 909.22 & 35 & 4.21 & 3.94 & 3.97 & 0 \\
2 & 6 & 897.22 & 33 & 4.13 & 4.06 & 3.84 & 0 \\
2 & 7 & 575.00 & 36 & 4.10 & 3.90 & 4.00 & 0 \\
3 & 8 & 298.81 & 23 & 4.10 & 4.04 & 3.91 & 0 \\
3 & 9 & 315.48 & 23 & 4.24 & 4.04 & 4.00 & 0 \\
4 & 9 & 97.78 & 7 & 4.20 & 4.04 & 3.88 & 0 \\
4 & 10 & 93.33 & 7 & 4.14 & 4.03 & 4.00 & 0 \\
5 & 9 & 148.21 & 23 & 4.23 & 4.01 & 4.03 & 0 \\
5 & 11 & 133.93 & 20 & 4.08 & 4.06 & 3.88 & 0 \\
6 & 12 & 2929.94 & 105 & 4.18 & 4.07 & 3.96 & 0 \\
7 & 13 & 4012.75 & 120 & 4.18 & 4.02 & 4.02 & 0 \\
7 & 14 & 4522.32 & 135 & 4.10 & 4.00 & 3.64 & 0 \\
7 & 15 & 4713.39 & 140 & 4.20 & 4.15 & 4.12 & 0
\end{array}\right]
$$

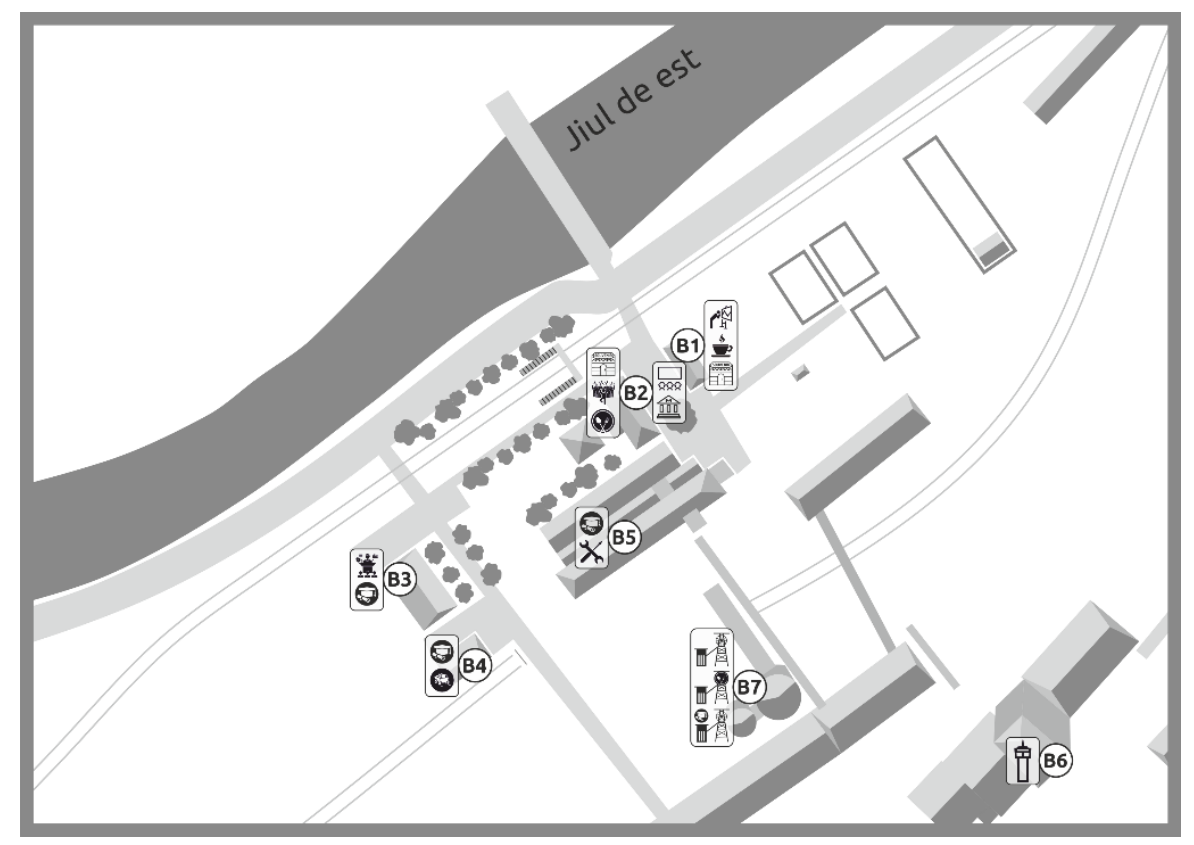

Figure 15. Destinations per buildings map.

The 5 criteria identified from the point of view of the contribution in the optimal choice are as follows: the technical-economic criteria are minimum type criteria, and the other three are maximum type criteria. For these criteria, the importance coefficients for calculating the acquired utility were established in vector Coef. Thus, the two vectors are:

$$
\begin{gathered}
\text { Coef }=\left[\begin{array}{ccccc}
0.133 & 0.067 & 0.333 & 0.267 & 0.200
\end{array}\right] \\
\text { Crit }=\left[\begin{array}{lllll}
0 & 0 & 1 & 1 & 1
\end{array}\right]
\end{gathered}
$$


After the first loop of the algorithm, the $C D_{-} U G$ matrix results, based on which the first form of candidate solution $P$ was determined, as presented in Figure 13. This candidate solution has to be validated as optimal solution.

$$
C D_{U G}=\left[\begin{array}{ccccccccccccccc}
0.29 & 0.8 & 0.27 & 0 & 0 & 0 & 0 & 0 & 0 & 0 & 0 & 0 & 0 & 0 & 0 \\
0 & 0 & 0.4 & 0.8 & 0.43 & 0.25 & 0.36 & 0 & 0 & 0 & 0 & 0 & 0 & 0 & 0 \\
0 & 0 & 0 & 0 & 0 & 0 & 0 & 0.46 & 0.86 & 0 & 0 & 0 & 0 & 0 & 0 \\
0 & 0 & 0 & 0 & 0 & 0 & 0 & 0 & 0.66 & 0.4 & 0 & 0 & 0 & 0 & 0 \\
0 & 0 & 0 & 0 & 0 & 0 & 0 & 0 & 0.53 & 0 & 0.46 & 0 & 0 & 0 & 0 \\
0 & 0 & 0 & 0 & 0 & 0 & 0 & 0 & 0 & 0 & 0 & 1 & 0 & 0 & 0 \\
0 & 0 & 0 & 0 & 0 & 0 & 0 & 0 & 0 & 0 & 0 & 0 & 0.66 & 0.05 & 0.8
\end{array}\right]
$$

$$
P=\left[\begin{array}{ccc}
1 & 2 & 0.8 \\
2 & 4 & 0.8 \\
3 & 9 & 0.86 \\
4 & 9 & 0.66 \\
5 & 9 & 0.53 \\
6 & 12 & 1 \\
7 & 15 & 0.8
\end{array}\right]
$$

The above candidate solution is represented in Figure 16a as building-destination correspondences, emphasizing in colour red on each line the destination selected by the algorithm in the first loop. The same results are presented in Figure $16 \mathrm{~b}$ as a map with buildings and destination icons.

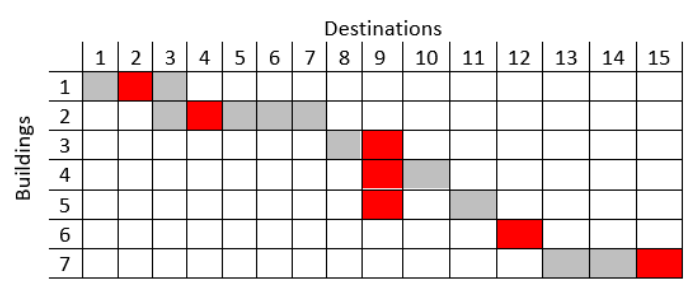

(a)

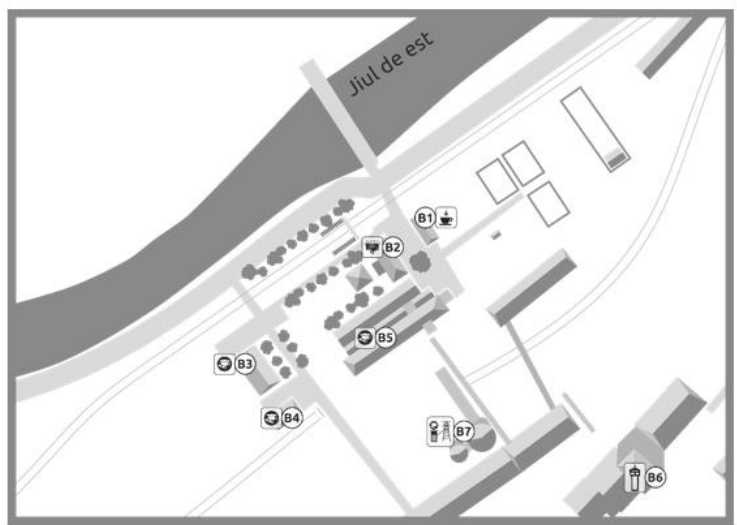

(b)

Figure 16. First loop running results: (a) Building-destination correspondences, (b) Map.

The results from running the first loop of the algorithm are presented in Figure 17.

As can be seen in the matrix $P$, we have destination 9 chosen for three buildings (buildings 3,4 and 5), which means that we will have a new running loop after choosing destination 9 for the building 3 , which brings the highest acquired utility.

As long as there is such a situation, the algorithm continues with a new loop until the optimal solution that satisfies the imposed constraint of uniqueness of destination choice is obtained. The new CD_UG matrix is: 


$$
C D \_U G=\left[\begin{array}{ccccccccccccccc}
0.29 & 0.8 & 0.27 & 0 & 0 & 0 & 0 & 0 & 0 & 0 & 0 & 0 & 0 & 0 & 0 \\
0 & 0 & 0.4 & 0.8 & 0.43 & 0.25 & 0.36 & 0 & 0 & 0 & 0 & 0 & 0 & 0 & 0 \\
0 & 0 & 0 & 0 & 0 & 0 & 0 & 0 & 1 & 0 & 0 & 0 & 0 & 0 & 0 \\
0 & 0 & 0 & 0 & 0 & 0 & 0 & 0 & 0 & 1 & 0 & 0 & 0 & 0 & 0 \\
0 & 0 & 0 & 0 & 0 & 0 & 0 & 0 & 0 & 0 & 1 & 0 & 0 & 0 & 0 \\
0 & 0 & 0 & 0 & 0 & 0 & 0 & 0 & 0 & 0 & 0 & 1 & 0 & 0 & 0 \\
0 & 0 & 0 & 0 & 0 & 0 & 0 & 0 & 0 & 0 & 0 & 0 & 0.66 & 0.05 & 0.8
\end{array}\right]
$$

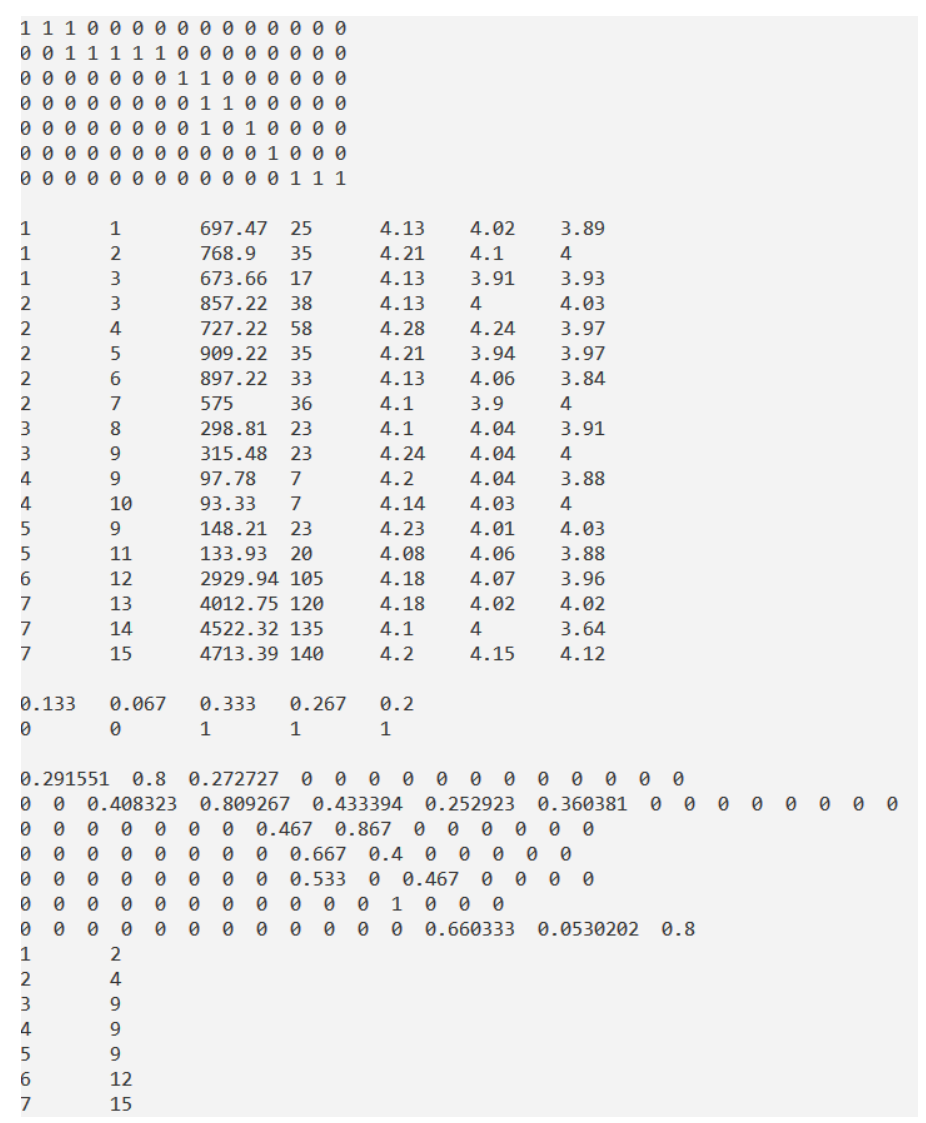

Figure 17. Numeric results.

The new candidate solution $P$ is:

$$
P=\left[\begin{array}{ccc}
1 & 2 & 0.8 \\
2 & 4 & 0.8 \\
3 & 9 & 1 \\
4 & 10 & 1 \\
5 & 11 & 1 \\
6 & 12 & 1 \\
7 & 15 & 0.8
\end{array}\right]
$$

As can be seen, the above candidate solution has no recurring destinations, which means that it is the final optimal solution, presented in Figure 18a as table and Figure 18b as map. 


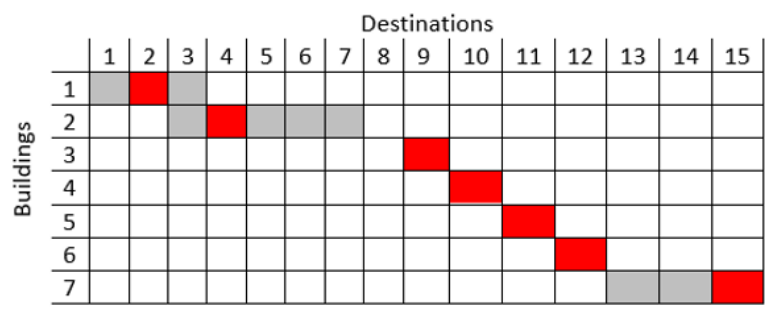

(a)

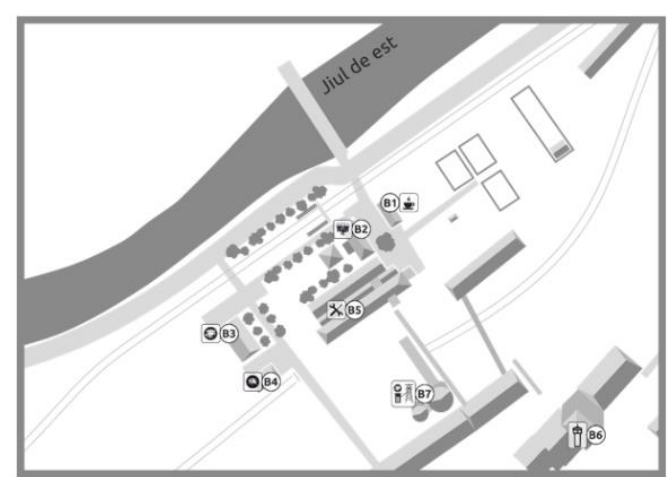

(b)

Figure 18. Final solution: (a) Building-destination correspondences, (b) Map.

The algorithm proved useful in the optimal selection of destinations and is a support tool in the further development of IHT for the studied area being supported by development scenarios mentioned in alternative strategies by stimulating entrepreneurship and innovation, development of the food industry, development of family micro farms, agritourism (traditional cuisine).

\section{Results}

Considering the massive restructuration of the mining activity, and implicitly of the personnel from the mining utilities, the implementation of methods and know-how means finding advanced solutions in order to use the available spaces-disaffected civil and industrial constructions through mining perimeters that were closed, in order to develop alternative activities by using the local or regional material base, for a social and economic recovery of disadvantaged area by using human resource by professional and social reorientation, must be considered.

The objectives of such a project involve adopting an interdisciplinary methodology; practically, different fields interfere here, such as geology, engineering sciences, urbanism, social sciences, applied informatics and management. As its base, there are a series of aspects referring to: a transversal analyse of elements of such a project, mainly geological context, knowing the environment, the demography and social economic state, the synthesis of weak and strong points; an evaluation of acceptability level, first based on quantitative social investigations, but also based on economical and even legal analysis; knowing the interactions between possible usage of a placement, as decisive element of orchestrating an approximate use and analysis of the potential of each existing objective (in this case, of buildings from the Petrila mining perimeter that were already included in the list of industrial patrimony) [66].

The paper presents the results of an inter and multidisciplinary research with applicability in a field considered topical and with great development potential, namely Industrial Heritage Tourism. The research gathers expertise from engineering and economic fields for the technical economic study; sociology for the study of the attitude of the inhabitants; applied informatics for the construction of the algorithm using Greedy, and management as the link between the fields that "intervenes" in the design of the algorithm by integrating the multicriteria analysis. This approach offers perspective to the research through the implementation of CBT. The paper has a proven practical applicability on the particular case of the Petrila area from Jiu Valley, Romania. Thus, the presented algorithm is an approach of valorization of the existing potential of IHT taking into account technical, economic and social aspects specific to the studied area.

Specifically, the results of the application of the algorithm are useful in the context of the need to revitalize the Petrila area. Thus, the theme park will be proposed based on the identified destinations of the buildings and will be evaluated the best constructive solutions will be evaluated, and then a business model (CBT Model), for which the premises were identified by this paper, will be constructed. 


\section{Discussion}

Greedy algorithms are among the simplest algorithms in combinatorial optimization; they are versatile and very useful in various fields and the Greedy paradigm is often used in the theory and practice of optimization. This approach has been widely generalized and studied by researchers in various fields, such as: biology, bioinformatics, optimization of wind turbine positioning, network routing, planning activities, routing problem, workflow, workstation scheduling.

Given that researchers' attention has focused on finding an efficient method of resource planning in project management, ref. [67] adapted the metaheuristic algorithm from [68], taking into account the specific characteristics of human resources involved in project, for Critical Chain Project Management (CCPM) with constraints on the human resources involved, as a variant of the Resource-Constrained Project Scheduling Problem (RCPSP) using Greedy algorithms. Thus, a sub-optimal solution generated by the Greedy algorithm was proposed, which identifies the current eligible activities, through independent tasks, trying to find a resource for each task. The resource is sought according to its impact on the project, in terms of the total time and/or cost of the project.

Ref. [69] proposes an algorithm for allocating employees' tasks according to their qualification and competencies in terms of cost efficiency involved, including training costs. The proposed solution is a modified Greedy algorithm with Meta-RaPS meta-heuristic.

Greedy algorithms are also used in planning tourism activities. When we talk about a tourist destination, we usually refer to numerous interconnected points of interest (scenic places, activities or shows) [70], and it is often impossible for tourists to visit all the points of interest during the limited time dedicated to the tour [71]. Therefore, tourists have to make a selection of points of interest that they consider most valuable to them [72] and determine the allocation of time during the tour. This issue has been termed the "problem of tourist travel design" [73]. For managers of tourist attraction locations, the problem of tourist travel design is a challenge that consists of planning various routes for tourists interested in visiting more than one points of interest to add value to the entertainment offer, taking into account a multitude of constraints.

Studies have shown the usefulness of simple or meta-heuristic Greedy algorithms in choosing the optimal routes in tourist locations with multiple points of interest taking into account one or more criteria imposed by the tourist (distances, budget, duration, types of points of interest, initial starting location, etc.).

The present research uses a modified Greedy algorithm with metaheuristics applied in the design stage of the park with several tourist destinations within the post-industrial site. For this case, the constraints introduced are related to the opportunity to choose destinations for existing buildings from a technical and economic (costs and duration), as well as social (local perception), perspective.

This approach of involving an optimal algorithm in the phase of constructing the theme park on the location of the old Petrila mine in order to ensure the best tourist experience, represents the originality of the research presented in this paper. The existing literature documents approaches of using the optimal algorithm only in selecting the tourist routes in existing touristic sites.

For example, in $[74,75]$ studies were conducted aimed at improving the algorithm needed to solve the problem of tourist travel design and present algorithms based on six tourist preferences, namely: total tour budget, number of days allocated to the tour, types of points of interest, types of packages, tour duration and the initial starting location. Tourists could select the starting location (i.e., hotel area), their budget, number of days, duration of the tour, types of points of interest (i.e., jungle trekking, island adventure, beaches and waterfall, history and culture, shopping and recreation). After setting preferences, the improved Greedy algorithm runs to build a complete package based on the set preferences. Ref. [76] uses the Greedy algorithm to determine the tourist route by linking 10 tourist attractions in Malang, Indonesia, and then implementing it in a website-based program. Ref. [77] proposes a Greedy algorithm for determining the ideal route to visit 8 of the 30 sights on the island of Langkawi, Malaysia, which is based on the distances between the sights included in the study. They use the Nearest Greedy and Nearest Greedy Insertion methods, as they are considered 
to be the most suitable to look for the best solution, directing them to visit the nearest place on the route until they have all been visited.

The results published in the literature confirm the validity of the application of the Greedy algorithm in tourism planning. Previous experience is focused on the stage of optimal planning of the existing patrimony. The current research in this paper focuses on the optimal design of the tourist site. Using the Greedy algorithm in both stages, the preparation of the tourist location and its use leads to the maximization of the tourists' satisfaction regarding the visit of the location, and to the prosperity of the locals. The solutions generated by the use of the algorithm are based on rigorous geo-technical, economic and social studies, included in the considered criteria, and can generate successful projects by involving key stakeholders, including the inhabitants. Studies so far have recognized the importance of the inhabitants' perception, but a further step was necessary that materialized in this paper by including the perception of economic, social and environmental effects in the algorithm of optimal selection, in addition to the aspects already known and used in the inception of projects of this type, namely, costs and duration.

\section{Conclusions, Limitations and Further Research Directions}

The algorithm was designed to meet a need that emerged after results were obtained from the preliminary studies. These results, in order to be capitalized on and materialized in projects, needed an integrative approach. First, technical studies were carried out which showed the possibilities of using the buildings for tourist purposes. Then, the obtained destinations were subjected to the "judgment" of the inhabitants. They are considered both as key stakeholders and direct beneficiaries of the rebirth of the studied area. The algorithm integrates these aspects by proposing an optimal solution in terms of a flexible number and type of criteria.

The generalization of the applicability of the algorithm allows obtaining the optimal solution using a different number and types of criteria depending on the specificity of the area to be studied.

As identified limitations, the algorithm captures the perception of the inhabitants at a certain moment, but this perception can change over time. In order to eliminate this limitation, a longitudinal study can be carried out on the attitude of the inhabitants, if the moment of starting the investment is delayed. The algorithm allows the adaptation of the number and type of criteria to the new requirements or identified perceptions.

Author Contributions: M.L. and A.I. conceived the research idea and designed the algorithm and experiments. I.S. was the author responsible for the residents' attitude towards IHT development study. M.T. performed the technical-economic study. All authors wrote the manuscript and have read and agreed to the published version of the manuscript.

Funding: This research received no external funding.

Conflicts of Interest: The authors declare no conflict of interest.

\section{References}

1. Xie, P.F. Developing industrial heritage tourism: A case study of the proposed jeep museum in Toledo, Ohio. Tour. Manag. 2006, 27, 1321-1330. [CrossRef]

2. Lee, T.H.; Jan, F.-H. Can community-based tourism contribute to sustainable development? Evidence from residents' perceptions of the sustainability. Tour. Manag. 2019, 70, 368-380. [CrossRef]

3. Lee, T.H. Influence analysis of community resident support for sustainable tourism development. Tour. Manag. 2013, 34, 37-46. [CrossRef]

4. Diedrich, A.; García-Buades, E. Local perceptions of tourism as indicators of destination decline. Tour. Manag. 2009, 30, 512-521. [CrossRef]

5. Hunt, C.; Stronza, A. Stage-based tourism models and resident attitudes towards, tourism in an emerging destination in the developing world. J. Sustain. Tour. 2014, 22, 279-298. [CrossRef]

6. Lundberg, E. The level of tourism development and resident attitudes: A comparative case study of coastal destinations. Scand. J. Hosp. Tour. 2015, 15, 266-294. [CrossRef] 
7. Stratton, M. Reviving industrial buildings. In Industrial Buildings: Conservation and Regeneration; Taylor \& Francis: London, UK, 2000; pp. 8-29.

8. Simonson, L.R. A Study of Industrial Plant Tours as Important Tourism Attractions. Ph.D. Thesis, Texas A\&M University, College Station, TX, USA, 1974.

9. Cox, L.J.; Fox, M. Agriculturally Based Leisure Attractions. J. Tour. Stud. 1991, 2, 18-27.

10. Pearce, P.L. Farm tourism in New Zeeland: A social situation analysis. Ann. Tour. Res. 1990, 17,337-352. [CrossRef]

11. MacCannell, D. The Tourist: A New Theory of the Leisure Class; Schocken Books: New York, NY, USA, 1976.

12. McBoyle, G. Industry's Contribution to Scottish Tourism: The Example of Malt Whisky Distilleries. In Tourism: State of the Art; Seaton, A.V., Ed.; Wiley: Chichester, UK, 1994; 528p.

13. Swarbrooke, J. The Development and Management of Visitors Attractions; Butterworth Heinemann: Oxford, UK, 1995.

14. Macionis, N. Wine tourism in Australia. In Tourism Down Under II: Towards a More Sustainable Tourism, Proceedings of the Tourism Research Conference, Dunedin, New Zealand, 3-6 December 1996; Kearsley, G., Ed.; Centre for Tourism, University of Otago: Dunedin, New Zealand, 1996; pp. 264-286.

15. Kelly, I.; Dixon, W. Sideline Tourism. J. Tour. Stud. 1991, 2, 21-28.

16. Yale, P. From Tourist Attractions to Heritage Tourism; Elm Publications: Huntingdon, UK, 1991.

17. Dodd, T.H.; Bigotte, V. Perceptual Differences Among Visitor Groups to Wineries. J. Travel Res. 1991, 35, 46-51. [CrossRef]

18. Frew, E.A. Industrial Tourism: A Conceptual and Empirical Analysis. Ph.D. Thesis, Victoria University, Melbourne, Australia, 2000.

19. Otgaar, A.H.J. Industrial Tourism: Where the public Meets the Private. Ph.D. Thesis, Erasmus University Rotterdam, Rotterdam, The Netherlands, 2010.

20. Falk, N. Our Industrial Heritage: A Resource for the Future. Planner 1989, 71, 13-16.

21. Hewison, R. Heritage Interpretation: The Natural and Built Environment. In The Heritage Industry: Social Representation of Heritage Interpretation; Uzzell, D., Ed.; Belhaven: London, UK, 1989; Volume 1, pp. $15-23$.

22. Briggs, C.S. Welsh Industrial Heritage: A Review; CBA Research Report No. 79; Council for British Archaeology: London, UK, 1992.

23. Prentice, R.C. Tourism and Heritage Attractions; Routledge: London, UK, 1993.

24. Harris, F. From the industrial revolution to the heritage industry. Geogr. Mag. 1989, 61, $38-42$.

25. Olgethorpe, M. Tourism and industrial Scotland. Tour. Manag. 1987, 8, 268-271.

26. Kerstetter, D.; Confer, J.J.; Bricker, K.S. Industrial Heritage Attractions: Types and Tourists. J. Travel Tour. Mark. 1998, 7, 91-104. [CrossRef]

27. Edwards, J.A.; Coit, J.C.L.I. Mines and quarries: Industrial heritage tourism. Ann. Tour. Res. 1996, 23, 341-363. [CrossRef]

28. Summerby-Murray, R. Interpreting deindustrialised landscapes of Atlantic Canada. Can. Geogr.Le Geographe Can. 2002, 46, 48-62. [CrossRef]

29. Firth, T.M. Tourism as a means to industrial heritage conservation: Achilles heel or saving grace? J. Herit. Tour. 2011, 6, 45-62. [CrossRef]

30. Caffyn, A.; Lutz, J. Developing the heritage tourism product in multi-ethnic cities. Tour. Manag. 1999, 20, 213-221. [CrossRef]

31. Halewood, C.; Hannam, K. Viking heritage tourism: Authenticity and commodification. Ann. Tour. Res. 2001, 28, 565-580. [CrossRef]

32. Oevermann, H.; Degenkolb, J.; Dießler, A.; Karge, S.; Peltz, U. Participation in the reuse of industrial heritage sites: The case of Oberschöneweide, Berlin. Int. J. Herit. Stud. 2016, 22, 43-58. [CrossRef]

33. Steinecke, A. Kulturtourismus in der Erlebnisgesellschaft: Trends, Strategien, Erfolgsfaktoren. Geogr. Sch. 2002, 24, 10-12.

34. Soyez, D. Industrietourismus. Erdkunde 1986, 40, 105-111. [CrossRef]

35. Mader, T. Produzierende Betriebe als Touristische Attraktionen im Reuhrgebiet: Grundlagen, Erscheinungsformen, Probleme. Master's Thesis, Heinrich-Heine Universitate, Dusseldorf, Germany, 2003.

36. Armis, R.; Kanegae, H. The attractiveness of a post-mining city as a tourist destination from the perspective of visitors: A study of Sawahlunto old coal mining town in Indonesia, Asia-Pacific. J. Reg. Sci. 2019, 4, 443-461. [CrossRef] 
37. Chhabra, D.; Healy, R.; Sills, E. Staged Authenticity and Heritage Tourism. Ann. Tour. Res. 2003, 30, 702-719. [CrossRef]

38. Lee, T.J.; Riley, M.; Hampton, M.P. Conflict and progress: Tourism development in Korea. Ann. Tour. Res. 2010, 37, 355-376. [CrossRef]

39. Vargas-Sánchez, A. Industrial Heritage and Tourism: A Review of the Literature. In The Palgrave Handbook of Contemporary Heritage Research; Palgrave Macmillan: London, UK, 2015; pp. 219-222.

40. Yang, X. Industrial heritage tourism development and city image reconstruction in Chinese traditional industrial cities: A web content analysis. J. Herit. Tour. 2017, 12, 267-280. [CrossRef]

41. Park, E.; Choi, B.K.; Lee, T.J. The role and dimensions of authenticity in heritage tourism. Tour. Manag. 2019, 74, 99-109. [CrossRef]

42. Adongo, R.; Choe, J.Y.; Han, H. Tourism in Hoi An, Vietnam: Impacts, perceived benefits, community attachment and support for tourism development. Int. J. Tour. Sci. 2017, 7, 86-106. [CrossRef]

43. Ka Leong, D.C. Heritage or hesitate? Preserving authenticity in Hong Kong tourism. Int. J. Tour. Sci. 2016, 16, 191-202. [CrossRef]

44. Bryce, D.; Curran, R.; O'Gorman, K.; Taheri, B. Visitors' engagement and authenticity: Japanese heritage consumption. Tour. Manag. 2015, 46, 571-581. [CrossRef]

45. Kolar, T.; Zabkar, V. A consumer-based model of authenticity: An oxymoron o the foundation of cultural heritage marketing? Tour. Manag. 2010, 31, 652-664. [CrossRef]

46. Xie, P.; Wall, G. Visitors' Perceptions of Authenticity at Cultural Attractions in Hainan, China. Int. J. Tour. Res. 2002, 4, 353-366. [CrossRef]

47. Zhou, Q.; Zhang, J.; Zhang, H.; Li, X. Is all authenticity accepted by tourists and residents? The concept, dimensions and formation mechanism of negative authenticity. Tour. Manag. 2018, 67, 59-70. [CrossRef]

48. Cantell, S.F. The Adaptive Reuse of Historic Industrial Buildings: Regulation Barriers, Best Practices and Case Studies. Master's Thesis, Virginia Polytechnic Institute and State University, Blacksburg, VA, USA, 2015.

49. Association "Valea Jiului Development Society Project", Valea Jiului Implicata. Available online: https: //www.valeajiuluiimplicata.org/tag/coalitia-vaii-jiului-implicata/ (accessed on 23 September 2020).

50. Toderaş, M. Rock Mechanics, Soil and Underground Constructions. Ph.D. Thesis, Universitas Publishing House, Petrosani, Romania, 2014; pp. 1-1167. (In Romanian).

51. Caamaño-Franco, I.; Andrade-Suárez, M.M. The Value Assessment and Planning of Industrial Mining Heritage as a Tourism Attraction: The Case of Las Médulas Cultural Space. Land 2020, 9, 404. [CrossRef]

52. Gursoy, D.; Jurowski, C.; Uysal, M. Resident Attitudes-A Structural Modelling Approach. Ann. Tour. Res. 2002, 29, 79-105. [CrossRef]

53. Hoffman, D.L.; Low, S.A. An Application of the Probit Transformation to Tourism Survey Data. J. Travel Res. 1981, 20, 35-38. [CrossRef]

54. Sheldon, P.J.; Var, T. Resident Attitudes to Tourism in North Wales. Tour. Manag. 1984, 5, 40-47. [CrossRef]

55. Ritchie, B.W.; Inkari, A. Host Community Attitudes Toward Tourism and Cultural Tourism Development: The Case of the Lewes District, Southern England. Int. J. Tour. Res. 2006, 8, 27-44. [CrossRef]

56. Andrade-Suárez, M.; Caamaño-Franco, I.I. The Relationship between Industrial Heritage, Wine Tourism, and Sustainability: A Case of Local Community Perspective. Sustainability 2020, 12, 7453. [CrossRef]

57. Xie, P.F.; Lee, M.Y.; Wong, J. Assessing community attitudes toward industrial heritage tourism development. J. Tour. Cult. Chang. 2019, 18, 237-251. [CrossRef]

58. Butler, R.W. The concept of a tourism areas cycles of evaluation: Implications for management of resources. Can. Geogr./Le Geographe Can. 1980, 24, 5-12. [CrossRef]

59. Levi-Strauss, C. The Elementary Structures of Kinship; Lippit, R., Polanski, N., Rosen, S., Eds.; Beacon Press: Boston, MA, USA, 1969.

60. Homans, G.C. Social Behaviour: Its Elementary Forms; Harcourt, Brace \& World, Inc.: New York, NY, USA, 1961.

61. Blau, P.M. Exchange and Power in Social Life; Wiley: New York, NY, USA, 1964.

62. Emerson, R. Power-Dependence Relations. Am. Sociol. Rev. 1972, 27, 38-87.

63. Ko, D.W.; Stewart, W.P. A structural equation model of residents' attitudes for tourism development. Tour. Manag. 2002, 23, 521-530. [CrossRef]

64. Vargas-Sanchez, A.; Porras-Bueno, N. Understanding Residents' Attitudes toward the Development of Industrial Tourism in a Former Mining Community. J. Travel Res. 2008, 47, 373-387. [CrossRef] 
65. Samuil, I.; Ionică, A.C.; Leba, M.; Noaghi, S.; Rocha, A. Towards a Business Model for Post-industrial Tourism Development in Jiu Valley, Romania. In Proceedings of the 8th World Conference on Information Systems and Technologies (WorldCist'20), Budva, Montenegro, 7-10 April 2020. AISC 1159.

66. Toderas, M.; Samuil, I.; Ionica, A.; Olar, M.; Militaru, S. Aspects regarding a mining area rehabilitation for post-industrial tourism. In MATEC Web of Conferences, Proceedings of the 9th International Conference on Manufacturing Science and Education-MSE 2019: Trends in New Industrial Revolution, Section Environment Engineering, Sibiu, Romania, 5-7 June 2019; Curran Associates, Inc.: Red Hook, NY, USA, 2019.

67. Pawinski, G.; Sapiecha, K. Cost-efficient project management based on critical chain method with partial availability of resources. Control Cybern. 2014, 43, 95-109.

68. Deniziak, S. Cost-efficient synthesis of multiprocessor heterogeneous systems. Control Cybern. 2004, 33, 341-355.

69. Douglas, A.M. A modified greedy algorithm for the task assignment problem. Master's Thesis, University of Louisville, Louisville, KY, USA, 2007.

70. Leiper, N. Tourist attraction systems. Ann. Tour. Res. 1990, 17, 367-384. [CrossRef]

71. Tsai, C.Y.; Chung, S.H. A personalized route recommendation service for theme parks using RFID information and tourist behavior. Decis. Support Syst. 2012, 52, 514-527. [CrossRef]

72. Souffriau, W.; Vansteenwegen, P.; Vertommen, J.; Berghe, G.V.; Oudheusden, D.V. A personalized tourist trip design algorithm for mobile tourist guides. Appl. Artif. Intell. 2008, 22, 964-985. [CrossRef]

73. Vansteenwegen, P.; Van Oudheusden, D. The mobile tourist guide: An OR opportunity. OR Insight 2007, 20, 21-27. [CrossRef]

74. Abdul-Rahman, S.; Benjamin, A.; Bakar, E.E.A. Economic tour package model using heuristic. AIP Conf. Proc. 2014, 1605, 1160-1165.

75. Benjamin, A.M.; Abdullah, A.S.; Abdul-Rahman, S.; Nazri1, E.M.; Yahaya, H.Z. Developing a Comprehensive Tour Package Using an Improved Greedy Algorithm with Tourist Preferences. J. Sustain. Sci. Manag. 2019, 14, 106-117.

76. Ghozali, A.E.; Setiawan, B.D.; Furqon, M.T. Tourism Planning Application in Malang with Greedy Algorithm (in Indonesia). J. Pengemb. Teknol. Inf. Ilmu Komput. 2017, 1, 1459-1467.

77. Hashim, Z.; Desa, W.L.H.M.; Aziz, H.A.; Zaki, N.M.Z.M. Greedy Method for Solving the Langkawi Tourist Route: A Case Study. J. Technol. Oper. Manag. 2018, 13, 18-25.

Publisher's Note: MDPI stays neutral with regard to jurisdictional claims in published maps and institutional affiliations.

(C) 2020 by the authors. Licensee MDPI, Basel, Switzerland. This article is an open access article distributed under the terms and conditions of the Creative Commons Attribution (CC BY) license (http://creativecommons.org/licenses/by/4.0/). 